\title{
REPORTS
}

\section{The Pharmacy Student Population: Applications Received 2014-15, Degrees Conferred 2014-15, Fall 2015 Enrollments}

\author{
Jamie N. Taylor, BA, Danielle A. Taylor, MPP, Nancy T. Nguyen, BA \\ American Association of Colleges of Pharmacy, Alexandria, Virginia
}

\section{INTRODUCTION}

This report presents data that describe the 2014-15 pharmacy application pool, degrees conferred in 2014-15, and fall 2015 pharmacy program enrollments. Data for this report were requested from the 135 U.S. colleges and schools of pharmacy recognized by the Accreditation Council for Pharmacy Education (ACPE) using five separate survey instruments.

There were previously two professional education programs at U.S. colleges and schools of pharmacy: one leading to a baccalaureate in pharmacy, and the other leading to the doctor of pharmacy (Pharm.D.) degree. However, June 30, 2005 marked the official expiration of the ACPE standards to the baccalaureate in pharmacy (B.S. Pharmacy) degree programs in accordance with the transition to the doctor of pharmacy (Pharm.D.) degree as the sole professional degree program in the U.S. Some colleges and schools of pharmacy conferred degrees in the B.S. Pharmacy program until 2004-05.

For the purpose of this report, students in doctor of pharmacy programs are categorized under Pharm.D.1 when the program leads to a doctor of pharmacy degree conferred as the first professional degree. Students who have already received a baccalaureate in pharmacy and are enrolled in a doctor of pharmacy degree program are categorized under Pharm.D.2.

The following definitions refer to the race/ethnicity groups as used in this report. White refers to U.S. citizens or permanent residents having origins in any of the original peoples of Europe, the Middle East, or North Africa. Black or African American refers to U.S. citizens or permanent residents having origins in any of the black racial groups of Africa. Hispanic or Latino refers to U.S. citizens or permanent residents of Cuban, Mexican, Puerto Rican, South or Central American, or other Spanish culture or origin, regardless of race. Asian refers to U.S. citizens or permanent residents having origins in any of the original peoples of the Far East, Southeast Asia, or the Indian Subcontinent, including, for example, Cambodia, China, India, Japan, Korea, Malaysia, Pakistan, the Philippine Islands, Thailand, and Vietnam. Native Hawaiian or Other Pacific Islander refers to U.S. citizens or permanent residents having origins in any of the original peoples of Hawaii, Guam, Samoa, or other Pacific Islands. Prior to 2011, these students were included in the Asian category. American Indian or Alaska Native refers to U.S. citizens or permanent residents having origins in any of the original peoples of North and South America (including Central America) who maintains cultural identification through tribal affiliation or community attachment. Two or More Races refers to U.S. citizens or permanent residents who are not Hispanic or Latino and identify themselves by more than one race. Unknown refers to U.S. citizens or permanent residents whose race and ethnicity are not known. Prior to 2011, this category was labeled Other/Unknown and students that were of two or more races were included in this category. Finally, International/Foreign refers to citizens of a foreign country/ permanent residents of a country other than the U.S.

\section{4-15 APPLICATION POOL}

The 2014-15 Application Pool Survey was conducted online in October 2015 with an announcement and request for participation sent to the survey coordinator at each of the 135 colleges and schools of pharmacy in the U.S. recognized by ACPE. After follow-up correspondence, 133 colleges and schools (98.5 percent) submitted the requested information. Included in the application pool are students who applied for admission and submitted all required application materials between September 2014 and August 2015 for the entering class of fall 2015. Numbers reported represent the number of applications, not applicants, and may represent multiple applications submitted by individual applicants.

During the period September 2014 through August 2015 the reporting institutions received 76,525 applications for admission.

In 2014-15, females submitted 59.9 percent of the applications to pharmacy colleges and schools; males submitted 39.2 percent; gender unknown/not reported submitted 0.8 percent. White Americans submitted 36.7 percent of the applications, Asian Americans submitted 32.4 percent of the applications, and underrepresented 


\section{American Journal of Pharmaceutical Education 2016; 80 (6) Article S3.}

Table 1. Distribution of 2014-15 Applications by Gender and Race/Ethnicity of Applicant ${ }^{\mathrm{a}}$

\begin{tabular}{lrrrr}
\hline Race/Ethnicity & Male & Female & Gender Not Specified & Total (\%) \\
\hline White $^{\text {b }}$ & 11143 & 16918 & 43 & $28104(36.7)$ \\
Black or African American $^{\text {b }}$ & 3769 & 5021 & 8 & $8798(11.5)$ \\
Hispanic or Latino $^{\text {b }}$ & 1510 & 2375 & 24 & $3909(5.1)$ \\
Asian $^{\text {b }}$ & 9662 & 15029 & 125 & $24816(32.4)$ \\
Native Hawaiian or Other Pacific Islander $^{\mathrm{b}}$ & 34 & 90 & 0 & $124(0.2)$ \\
American Indian or Alaska Native $^{\mathrm{b}}$ & 52 & 115 & 0 & $167(0.2)$ \\
Two or more races $^{\mathrm{b}}$ & 1283 & 2138 & 2 & $3423(4.5)$ \\
Unknown $^{\mathrm{b}}$ & 1498 & 2278 & 399 & $4175(5.5)$ \\
International/Foreign $^{\mathrm{c}}$ & 1072 & 1907 & 30 & $3009(3.9)$ \\
Total & 30023 & 45871 & 631 & 76525 \\
\hline
\end{tabular}

${ }^{a}$ Represents data, some incomplete, submitted by 133 schools

${ }^{b}$ U.S. citizen or permanent resident

${ }^{\mathrm{c}}$ Citizens of a foreign country/permanent residents of a country other than the U.S

minorities submitted 17.0 percent of the applications (Black or African American, 11.5 percent; Hispanic or Latino, 5.1 percent; Native Hawaiian or Other Pacific Islander, 0.2 percent; American Indian or Alaska Native, 0.2 percent). Applications submitted from students that identified as two or more races totaled 4.5 percent and 3.9 percent of the applications were submitted by foreign, nonpermanent residents [Table 1]. For the eleventh consecutive year, colleges and schools of pharmacy received more applications from out-of-state residents (54.2 percent) compared to 45.8 percent from in-state residents. The higher percentage of out-of-state applicants can be attributed to the ease of applying to colleges and schools of pharmacy in different states through PharmCAS.

Over 72 percent ( 72.7 percent) of the applications to colleges and schools of pharmacy were submitted by individuals who had 3 or more years of postsecondary experience ( 3 or more years of college/no degree, 25.0 percent; baccalaureate, 45.4 percent; master's, 1.9 percent; doctoral degree, 0.4 percent), [Table 2].

\section{4-15 DEGREES CONFERRED}

The 2014-15 Undergraduate and Professional Pharmacy Degrees Conferred and Graduate Pharmacy Degrees
Conferred surveys were conducted online in October 2015, with an announcement and request for participation sent to the survey coordinator at each of the 135 colleges and schools of pharmacy in the U.S. recognized by ACPE. Submission of the data was requested by December 2015. After follow-up correspondence, 132 colleges and schools (97.8 percent) submitted the Undergraduate and Professional Degrees Conferred Survey and 133 institutions (98.5 percent) completed the Graduate Degrees Conferred Survey.

\section{Professional Degrees Conferred}

Numbers of degrees conferred by U.S. colleges and schools of pharmacy from 1965 to 2015 are presented in Table 3.

\section{First Professional Degrees Conferred}

In 2014-15 123 colleges and schools of pharmacy reported conferring the doctor of pharmacy as a first professional degree (Pharm.D.1). Graduating Pharm.D.1 class sizes ranged from 31 students to 307 students (median, 98 students). Nine of the 132 colleges and schools did not confer degrees in 2014-15. These schools were new programs whose students had not yet progressed through the entire curriculum (California Health Sciences,

Table 2. Distribution of 2014-15 Applications to First Professional Degree Programs by Gender and Previous Postsecondary Experience of Applicant ${ }^{\mathrm{a}}$

\begin{tabular}{lrrrr}
\hline Postsecondary Experience & Male & Female & Gender Not Specified & Total (\%) \\
\hline 0 Years of College & 3973 & 5945 & 711 & $10629(13.9)$ \\
1-2 Years of College/No Degree & 1723 & 2954 & 117 & $4794(6.3)$ \\
Associate's Degree & 2099 & 3056 & 257 & $5412(7.1)$ \\
3 or More Years of College/No Degree & 7384 & 11389 & 297 & $19070(25.0)$ \\
Baccalaureate Degree & 13612 & 20278 & 735 & $34625(45.4)$ \\
Master's Degree & 670 & 724 & 19 & $1413(1.9)$ \\
Doctoral Degree & 137 & 145 & 8 & $290(0.4)$ \\
\hline
\end{tabular}

${ }^{a}$ Represents data, some incomplete, submitted by 133 schools 
American Journal of Pharmaceutical Education 2016; 80 (6) Article S3.

Table 3. Number of Pharmacy Degrees Conferred 1965-2015 by Degree and Gender

\begin{tabular}{|c|c|c|c|c|c|c|c|c|c|c|c|c|c|c|c|c|c|c|}
\hline \multirow[b]{2}{*}{ Year } & \multicolumn{3}{|c|}{ BS Pharmacy ${ }^{\mathrm{a}}$} & \multicolumn{3}{|c|}{ PharmD1 $^{\text {b }}$} & \multicolumn{3}{|c|}{ First Professional $^{\mathrm{c}}$} & \multicolumn{3}{|c|}{ PharmD2 $^{\mathrm{d}}$} & \multicolumn{3}{|c|}{ MS } & \multicolumn{3}{|c|}{ PhD } \\
\hline & M & $\mathbf{F}$ & $\mathbf{T}$ & $\mathbf{M}$ & $\mathbf{F}$ & $\mathbf{T}$ & $\mathbf{M}$ & $\mathbf{F}$ & $T$ & M & F & $\mathbf{T}$ & M & $\mathbf{F}$ & $\mathbf{T}$ & M & $\mathbf{F}$ & $\mathbf{T}$ \\
\hline 1965 & 2723 & 454 & 3177 & 162 & 21 & & 2885 & 475 & 3360 & & & & 150 & 26 & 176 & 105 & 3 & 108 \\
\hline 1966 & 970 & 500 & & 161 & & & & & & & & & & 38 & 190 & 108 & 15 & 123 \\
\hline 967 & 078 & 493 & 571 & 136 & 3 & 173 & 214 & & & & & & 235 & 32 & 267 & 118 & 8 & 126 \\
\hline 968 & 194 & 572 & 766 & 183 & 3 & & 3377 & 611 & & & & & 219 & 44 & 263 & 124 & 10 & 134 \\
\hline 69 & 384 & 695 & 4079 & 178 & 3 & & 3562 & & 4288 & & & & 235 & 42 & 277 & 136 & 9 & 145 \\
\hline 970 & 664 & 853 & 4517 & 192 & 4 & 241 & 856 & 902 & 4758 & & & & 236 & 54 & 290 & 131 & 10 & 141 \\
\hline 971 & 589 & 935 & 4524 & 160 & 6 & & 749 & 998 & 4747 & & & & 219 & 56 & 275 & 169 & 8 & 177 \\
\hline 972 & 3498 & 1072 & 4570 & 215 & 7 & 288 & 3713 & 1145 & 4858 & & & & 205 & 56 & 261 & 155 & 13 & 168 \\
\hline 973 & 674 & 259 & 4933 & 184 & 6 & & 3858 & & & 99 & 18 & 117 & 273 & 53 & 326 & 172 & 15 & 187 \\
\hline 974 & 4104 & 559 & 5663 & 205 & & & 4309 & & & 117 & 23 & 140 & 250 & 70 & 320 & 165 & 19 & 184 \\
\hline 975 & 4607 & 792 & 6399 & 218 & & & 4825 & & & 110 & 26 & 136 & 250 & 89 & 339 & 165 & 24 & 189 \\
\hline 976 & 4940 & 2165 & 7105 & 250 & 109 & & 5190 & & & 88 & 38 & 126 & 301 & 92 & 393 & 163 & 26 & 189 \\
\hline 977 & 5108 & 541 & 7649 & 255 & & & 5363 & & & 147 & 42 & 189 & 309 & 90 & 399 & 147 & 19 & 166 \\
\hline 978 & 4715 & 2715 & 7430 & 246 & & & 4961 & & & 132 & & 197 & 305 & 117 & 422 & 158 & 20 & 178 \\
\hline 979 & 4260 & 2835 & 7095 & 278 & & & & & & & & 190 & 301 & 134 & 435 & 125 & 28 & \\
\hline 80 & 4154 & 2831 & 6985 & 26 & & & & & & 120 & 60 & & 315 & 150 & & 155 & 34 & \\
\hline 81 & 3753 & & 6869 & 26 & & & & & & 109 & & & 71 & 163 & & & 28 & \\
\hline 82 & 417 & & & & & & & & & 119 & & & 93 & 165 & & & 36 & \\
\hline 83 & 2994 & & & & & & & & & 136 & & & 77 & 149 & & & 54 & \\
\hline 84 & 2826 & 272 & & & & & & & & 169 & & & & 141 & & & 53 & 227 \\
\hline 85 & 2362 & & & & & & & & & 121 & & & 0 & 28 & & & 57 & 232 \\
\hline 6 & 370 & 28 & 51 & 27 & & & & & & 77 & & & 15 & & & & 68 & \\
\hline 7 & 235 & & & 29 & & & & & & 6 & & & 97 & & & & 80 & 83 \\
\hline 8 & 245 & & & 32 & & & & & & 4 & & & 4 & & & & 75 & 63 \\
\hline 9 & 313 & & & 31 & & & & & & 9 & & & 26 & & & 75 & 112 & 87 \\
\hline 0 & 393 & & & 38 & & & & & & 118 & & & 2 & & & 1 & 92 & 73 \\
\hline 991 & 268 & & & 43 & & & & & & 6 & & & 39 & & & 01 & 112 & 13 \\
\hline 992 & 261 & & & 43 & & & & & & 4 & & & & & & 95 & 22 & 17 \\
\hline & 244 & & & 46 & & & & & & & & & & & & 3 & 5 & \\
\hline 94 & 274 & & & 43 & & & & & & & & & & & & 198 & 22 & \\
\hline 95 & 291 & & & 55 & & & & & & & & & & & & 218 & 32 & \\
\hline 96 & 311 & & & 58 & & & & & & & & & & & & 186 & 18 & 304 \\
\hline 7 & 212 & & & 69 & & & & & & & & & & & & 218 & 40 & \\
\hline & & & & & & & & & & & & & & & & & 73 & 411 \\
\hline & 152 & & & 1 & & & & & & & & & & & & 22 & 38 & 359 \\
\hline & 111 & & & & & & & & & & & & & & & 17 & 49 & 323 \\
\hline & & & & & & & & & & & & & & & & 211 & 64 & 375 \\
\hline & 54 & & 141 & 2055 & & & & & & 276 & & & 1 & 26 & & 216 & 160 & 376 \\
\hline & 30 & & & 2333 & & & & & & & & & 1 & 27 & & 210 & 174 & 384 \\
\hline & 153 & & 388 & 2568 & & & & & & 277 & & & & & & 176 & 59 & 335 \\
\hline & 16 & 10 & 26 & 2618 & & & & & & 241 & 4 & & 23 & & 62 & 215 & 214 & 429 \\
\hline & 0 & & 0 & 2875 & & & & & & 202 & 3 & & 24 & 40 & & 252 & 190 & 442 \\
\hline & ( & & 0 & 3171 & & & & & & 97 & 37 & & 236 & 36 & 60 & 220 & 192 & 412 \\
\hline & ( & & 0 & & & & & & & & 4 & & 275 & 457 & 73 & 262 & 206 & 468 \\
\hline & 0 & & 0 & & & & & & & & 32 & & 371 & 396 & 767 & 228 & 230 & 458 \\
\hline & 0 & & 0 & & 720 & & & & & & 3 & & 34 & 430 & 773 & 243 & 207 & 450 \\
\hline & 0 & & 0 & & & & & & & & 2 & & 352 & 470 & 822 & 250 & 221 & 471 \\
\hline 2012 & 0 & 0 & 0 & 4937 & 7782 & 12719 & 4937 & 7782 & 12719 & 163 & 281 & 444 & 298 & 383 & 681 & 275 & 222 & 497 \\
\hline
\end{tabular}

(Continued) 


\section{American Journal of Pharmaceutical Education 2016; 80 (6) Article S3.}

Table 3. (Continued)

\begin{tabular}{|c|c|c|c|c|c|c|c|c|c|c|c|c|c|c|c|c|c|c|}
\hline \multirow[b]{2}{*}{ Year } & \multicolumn{3}{|c|}{ BS Pharmacy ${ }^{\mathrm{a}}$} & \multicolumn{3}{|c|}{ PharmD1 $^{\text {b }}$} & \multicolumn{3}{|c|}{ First Professional $^{c}$} & \multicolumn{3}{|c|}{ PharmD2 $^{\text {d }}$} & \multicolumn{3}{|c|}{ MS } & \multicolumn{3}{|c|}{ PhD } \\
\hline & $\mathbf{M}$ & $\mathbf{F}$ & $\mathbf{T}$ & M & $\mathbf{F}$ & $\mathbf{T}$ & M & $\mathbf{F}$ & $T$ & M & $\mathbf{F}$ & $T$ & M & F & $T$ & M & $\mathbf{F}$ & $T$ \\
\hline 2013 & 0 & 0 & 0 & 5063 & 8144 & 13207 & 5063 & 8144 & 13207 & 132 & 212 & 344 & 265 & 390 & 655 & 293 & 296 & 589 \\
\hline 2014 & 0 & 0 & 0 & 5483 & 8355 & 1383 & 5483 & 8355 & 13838 & 110 & 229 & 339 & 340 & 435 & 775 & 298 & 267 & 565 \\
\hline 2015 & 0 & 0 & 0 & 5369 & 8625 & 13994 & 5369 & 8625 & 13994 & 88 & 185 & 273 & 326 & 394 & 720 & 312 & 249 & 561 \\
\hline
\end{tabular}

${ }^{a}$ Includes BPharm Degree

${ }^{\mathrm{b}} \mathrm{PharmD} 1$ refers to the doctor of pharmacy degree awarded as the first professional degree

${ }^{\mathrm{c}}$ Includes BS Pharmacy, BPharm, and PharmD1

${ }^{\mathrm{d}} \mathrm{PharmD} 2$ refers to the doctor of pharmacy degree awarded as a postbaccalaureate degree

Chapman, Keck Graduate Institute, Fairleigh Dickinson, Manchester, Marshall, Cedarville, North Texas, and Texas at Tyler).

In 2014-15 there were 13,994 first professional degrees conferred by colleges and schools compared to 13,838 in 2013-14 [Table 4]. The total number of first professional degrees conferred in 2014-15 represented a 1.1 percent increase from the total number of first professional degrees conferred in 2013-14 [Table 5].

In $1979-80$, men received 59.5 percent of the first professional degrees conferred by colleges and schools and women received 40.5 percent. Over the past 35 years, these percentages have shifted dramatically and, in 201415 , men received 38.4 percent of the first professional degrees conferred and 61.6 percent of these degrees were received by women. Women received the highest percentage of degrees conferred in 2005-06 (68.2 percent) [Table 6].

White Americans received 54.7 percent of first professional degrees conferred in 2014-15. Asian Americans received 24.6 percent of the first professional degrees. Underrepresented minorities received 11.8 percent of the first professional degrees conferred in 2014-15 (Black or African American, 6.9 percent; Hispanic or Latino, 4.1 percent; Native Hawaiian or Other Pacific Islander, 0.3 percent; American Indian or Alaska Native, 0.5 percent). The percentage of first professional degree recipients who were of two or more races was 1.8 percent and the percentage of recipients who were foreign, nonpermanent residents of the U.S. was 2.9 percent [Table 7].

\section{Doctor of Pharmacy Degrees Conferred to Post Baccalaureate Students}

Seven colleges and schools conferred the Pharm.D. degree to post baccalaureate students in 2014-15. The number of graduates per institution ranged from 4 to 105 students (median, 37 students). The number of doctor of pharmacy degrees conferred as postbaccalaureate degrees (Pharm.D.2) decreased by 19.5 percent to 273 in 2014-15 from 339 in 2013-14 [Table 5]. More women than men received Pharm.D.2 degrees in 2014-15 (women, 67.8 percent; men, 32.2 percent) [Table 6].

White Americans received 31.5 percent of Pharm. D. 2 degrees conferred in 2014-15. Asian Americans received 18.3 percent of the Pharm.D.2 degrees conferred. Underrepresented minorities received 14.3 percent of the Pharm.D.2 degrees conferred (black, 10.6 percent; Hispanic or Latino, 3.3 percent; Native Hawaiian or Other Pacific Islander, 0.0 percent; American Indian or Alaska Native, 0.4 percent). Students of two or more races received 0.0 of Pharm.D. 2 degrees conferred in 2014-15 The percentage of Pharm.D.2 degree recipients who were foreign, nonpermanent residents of the U.S. was 17.9 percent, up from 10.0 percent in 2013-14 [Table 8].

\section{Graduate Degrees Conferred}

The number of graduate degrees (M.S. and Ph.D.) conferred has shown annual fluctuations over the 50 years data have been consistently gathered and reported [Table 3]. The number of M.S. degrees conferred decreased to 720 in 2014-15 from 775 in 2013-14, a 7.1 percent decrease. The number of Ph.D. degrees conferred decreased in 2014-15 to 561 from 565 in 2013-14 (0.7 percent decrease) [Table 5].

The highest percentage of M.S. degrees awarded in 2014-15 (26.4 percent) was in pharmaceutics. The second highest percentage of M.S. degrees was in social and administrative sciences (25.1 percent); followed by pharmacology (19.3 percent); other disciplines (15.8 percent); medicinal chemistry ( 7.8 percent); and pharmacy practice (5.6 percent). The highest number of Ph.D. degrees awarded in 2014-15 was also in the discipline of pharmaceutics (38.7 percent). The second highest number was in medicinal chemistry (23.7 percent); followed by pharmacology (16.8 percent); social and administrative sciences (9.4 percent); other disciplines (8.2 percent); and pharmacy practice (3.2 percent) [Table 9].

More women than men earned M.S. degrees (women, 54.7 percent; men, 45.3 percent); however, more men than women earned Ph.D. degrees (women, 44.4 percent; men, 


\section{American Journal of Pharmaceutical Education 2016; 80 (6) Article S3.}

Table 4. Baccalaureate and Doctor of Pharmacy (PharmD1) Degrees as Percentages of Total First Professional Degrees Conferred 1981-2015

\begin{tabular}{|c|c|c|c|}
\hline & BS Pharmacy ${ }^{\text {a }}$ & PharmD1 $^{\text {b }}$ & First Professional $^{c}$ \\
\hline Year & n $(\%)$ & n $(\%)$ & $\mathbf{n}$ \\
\hline 1981 & $6869(93.8)$ & $454(6.2)$ & 7323 \\
\hline 1982 & $6448(94.0)$ & $411(6.0)$ & 6859 \\
\hline 1983 & $5919(92.9)$ & $455(7.1)$ & 6374 \\
\hline 1984 & $5546(93.0)$ & $417(7.0)$ & 5963 \\
\hline 1985 & $5147(89.7)$ & $588(10.3)$ & 5735 \\
\hline 1986 & $5190(89.5)$ & $610(10.5)$ & 5800 \\
\hline 1987 & $5164(88.2)$ & $690(11.8)$ & 5854 \\
\hline 1988 & $5371(86.9)$ & $813(13.1)$ & 6184 \\
\hline 1989 & $5721(87.3)$ & $839(12.7)$ & 6560 \\
\hline 1990 & $6010(86.4)$ & $946(13.6)$ & 6956 \\
\hline 1991 & $5927(83.2)$ & 1195 (16.8) & 7122 \\
\hline 1992 & 5897 (82.9) & $1216(17.1)$ & 7113 \\
\hline 1993 & $6031(81.7)$ & 1349 (18.3) & 7380 \\
\hline 1994 & $6145(81.9)$ & $1359(18.1)$ & 7504 \\
\hline 1995 & $6218(79.3)$ & 1619 (20.7) & 7837 \\
\hline 1996 & $6168(77.1)$ & $1835(22.9)$ & 8003 \\
\hline 1997 & $5768(74.2)$ & $2004(25.8)$ & 7772 \\
\hline 1998 & 4768 (64.4) & $2632(35.6)$ & 7400 \\
\hline 1999 & $3876(54.3)$ & $3265(45.7)$ & 7141 \\
\hline 2000 & $2956(40.7)$ & $4304(59.3)$ & 7260 \\
\hline 2001 & $1914(27.3)$ & $5086(72.7)$ & 7000 \\
\hline 2002 & 1415 (18.7) & $6158(81.3)$ & 7573 \\
\hline 2003 & 839 (11.2) & $6649(88.8)$ & 7488 \\
\hline 2004 & $388(4.8)$ & $7770(95.2)$ & 8158 \\
\hline 2005 & $26(0.3)$ & 8242 (99.7) & 8268 \\
\hline 2006 & $0(0.0)$ & $9040(100.0)$ & 9040 \\
\hline 2007 & $0(0.0)$ & $9812(100.0)$ & 9812 \\
\hline 2008 & $0(0.0)$ & $10500(100.0)$ & 10500 \\
\hline 2009 & $0(0.0)$ & $10988(100.0)$ & 10988 \\
\hline 2010 & $0(0.0)$ & $11487(100.0)$ & 11487 \\
\hline 2011 & $0(0.0)$ & $11931(100.0)$ & 11931 \\
\hline 2012 & $0(0.0)$ & $12719(100.0)$ & 12719 \\
\hline 2013 & $0(0.0)$ & $13207(100.0)$ & 13207 \\
\hline 2014 & $0(0.0)$ & $13838(100.0)$ & 13838 \\
\hline 2015 & $0(0.0)$ & $13994(100.0)$ & 13994 \\
\hline
\end{tabular}

ancludes BPharm degree

${ }^{\mathrm{b}} \mathrm{PharmD} 1$ refers to the doctor of pharmacy degree awarded as the first professional degree

${ }^{\mathrm{c} I n c l u d e s ~ B S ~ P h a r m a c y, ~ B P h a r m, ~ a n d ~ P h a r m D 1 ~}$

55.6 percent) in 2014-15. There have only been two years (2012-13 and 2008-09) since AACP began collecting data that women received more Ph.D. degrees than men. The percentage of women receiving Ph.D. degrees decreased from 47.3 percent in 2013-14 to 44.4 percent in 2014-15; however, the number of Ph.D. degrees received by women has grown substantially from 18.0 percent in 1979-80 [Table 6]. This increase can be partially attributed to an increase in the number of foreign females receiving Ph.D. degrees [Table 10].
Underrepresented minorities received 6.7 percent of the M.S. degrees conferred in 2014-15 (Black or African American, 3.9 percent; Hispanic or Latino, 2.8 percent; Native Hawaiian or Other Pacific Islander, 0.0 percent; American Indian or Alaska Native, 0.0 percent), a decrease from 7.2 percent in 2013-14. Asian Americans received 11.7 percent of the M.S. degrees conferred, up from 9.7 percent in 2013-14. The percentage of M.S. degree recipients who were of two or more races was 1.1 percent and the percent of degree recipients who were foreign, nonpermanent residents of the U.S. was 48.8 percent, down from 49.8 percent in 2013-14 [Table 11].

Underrepresented minorities earned 5.7 percent of the Ph.D. degrees awarded in 2014-15 (Black or African American, 3.2 percent; Hispanic or Latino, 2.3 percent; Native Hawaiian or Other Pacific Islander, 0.0 percent; American Indian or Alaska Native, 0.2 percent), a decrease from 6.8 percent in 2013-14. Asian Americans earned 16.0 percent of the Ph.D. degrees awarded. The percentage of $\mathrm{Ph}$.D. degree recipients who were of two or more races was 0.4 percent and the percentage of degree recipients that were foreign, nonpermanent residents of the U.S. was 45.6 percent, down from 48.5 percent in 2013-14 [Table 12].

\section{FALL 2015 ENROLLMENTS}

The 2015 Undergraduate and Professional Pharmacy Degree Enrollment Survey and Graduate Degree Enrollment Survey were conducted online in October 2015, with an announcement and request for participation sent to the survey coordinator at each of the 135 colleges and schools of pharmacy in the U.S. recognized by ACPE. Submission of the data was requested by December 2015 . After follow-up correspondence, 133 colleges and schools ( 98.5 percent) submitted the requested information.

\section{Professional Degree Programs}

Fall 2015 enrollments in the Pharm.D. as the first professional degree programs $(n=63,460)$ represented a 0.7 percent decrease from enrollments in fall 2014 $(n=63,927)$ [Table 13]. In fall 2015, 61.4 percent of the students enrolled in the Pharm.D. as the first professional degree programs were females and 38.6 percent were males [Table 14].

White Americans comprised the majority (51.6 percent) of students enrolled in the Pharm.D. as the first professional degree programs. Asian Americans accounted for 25.3 percent; Black or African Americans, 7.9 percent; Hispanic or Latino, 5.0 percent; Native Hawaiians/ Other Pacific Islanders. 0.4 percent; American Indians/ Alaska Natives, 0.3 percent; and international/foreign students, 3.1 percent. Students that identified as two or 
American Journal of Pharmaceutical Education 2016; 80 (6) Article S3.

Table 5. Annual Percentage Change in Number of Pharmacy Degrees Conferred 1981-2015 Over Previous Year

\begin{tabular}{|c|c|c|c|c|}
\hline Year & $\frac{\text { First Professional }^{\mathrm{a}}}{\text { No. (\% Change) }}$ & $\frac{\text { PharmD2 }^{\mathrm{b}}}{\text { No. }(\% \text { Change })}$ & $\frac{\text { MS }}{\text { No. (\% Change })}$ & $\frac{\text { PhD }}{\text { No. (\% Change) }}$ \\
\hline 1981 & $7323(-1.5)$ & $210(+16.7)$ & $434(-6.7)$ & $180(-4.8)$ \\
\hline 1982 & $6859(-6.3)$ & $207(-1.4)$ & $458(+5.5)$ & $182(+1.1)$ \\
\hline 1983 & $6374(-7.1)$ & $271(+30.9)$ & $426(-7.0)$ & $208(+14.3)$ \\
\hline 1984 & $5963(-6.4)$ & $331(+22.2)$ & $394(-7.5)$ & $227(+9.1)$ \\
\hline 1985 & $5735(-3.8)$ & $224(-32.3)$ & $338(-14.2)$ & $232(+2.2)$ \\
\hline 1986 & $5800(+1.1)$ & $210(-6.3)$ & $415(+22.8)$ & $260(+12.1)$ \\
\hline 1987 & $5854(+0.9)$ & $212(+1.0)$ & $348(-16.1)$ & $283(+8.8)$ \\
\hline 1988 & $6184(+5.6)$ & $159(-25.0)$ & $353(+1.4)$ & $263(-7.1)$ \\
\hline 1989 & $6560(+6.0)$ & $222(+39.6)$ & $391(+10.8)$ & $287(+9.1)$ \\
\hline 1990 & $6956(+6.0)$ & $302(+36.0)$ & $385(-1.5)$ & $273(-4.9)$ \\
\hline 1991 & $7122(+2.4)$ & $271(-10.3)$ & $364(-5.5)$ & $313(+14.7)$ \\
\hline 1992 & $7113(-0.1)$ & $286(+5.5)$ & $282(-22.5)$ & $317(+1.3)$ \\
\hline 1993 & $7380(+3.8)$ & $396(+38.5)$ & $301(+6.7)$ & $348(+9.8)$ \\
\hline 1994 & $7504(+1.7)$ & $575(+45.2)$ & $355(+17.9)$ & $320(-8.0)$ \\
\hline 1995 & $7837(+4.4)$ & $704(+22.4)$ & $392(+10.4)$ & $350(+9.4)$ \\
\hline 1996 & $8003(+2.1)$ & $732(+4.0)$ & $422(+7.7)$ & $304(-13.1)$ \\
\hline 1997 & $7772(-2.9)$ & $859(+17.3)$ & $400(-5.2)$ & $358(+17.8)$ \\
\hline 1998 & $7400(-4.8)$ & $1014(+18.0)$ & $421(+5.3)$ & $411(+14.8)$ \\
\hline 1999 & $7141(-3.5)$ & $913(-10.0)$ & $384(-8.8)$ & $359(-12.7)$ \\
\hline 2000 & $7260(+1.7)$ & $1269(+39.0)$ & $354(-7.8)$ & $323(-10.0)$ \\
\hline 2001 & $7000(-3.6)$ & $979(-22.9)$ & $461(+30.2)$ & $375(+16.1)$ \\
\hline 2002 & $7573(+8.2)$ & $780(-20.3)$ & $443(-3.9)$ & $376(+0)$ \\
\hline 2003 & $7488(-1.1)$ & $895(+14.7)$ & $472(+6.5)$ & $384(+2.1)$ \\
\hline 2004 & $8158(+8.9)$ & $756(-15.5)$ & $651(+37.9)$ & $335(-12.8)$ \\
\hline 2005 & $8268(+1.3)$ & $668(-11.6)$ & $626(-3.8)$ & $429(+28.1)$ \\
\hline 2006 & $9040(+9.3)$ & $515(-22.9)$ & $644(+2.9)$ & $442(+3.0)$ \\
\hline 2007 & $9812(+8.5)$ & $470(-8.7)$ & $604(-6.2)$ & $412(-6.8)$ \\
\hline 2008 & $10500(+7.0)$ & $627(+33.4)$ & $732(+21.2)$ & $468(+13.6)$ \\
\hline 2009 & $10988(+4.6)$ & $528(-15.8)$ & $767(+4.8)$ & $458(-2.1)$ \\
\hline 2010 & $11487(+4.5)$ & $527(-0.2)$ & $773(+0.8)$ & $450(-1.7)$ \\
\hline 2011 & $11931(+3.9)$ & $415(-21.3)$ & $822(+6.3)$ & $471(+4.7)$ \\
\hline 2012 & $12719(+6.6)$ & $444(+7.0)$ & $681(-17.2)$ & $497(+5.5)$ \\
\hline 2013 & $13207(+3.8)$ & $344(-22.5)$ & $655(-3.8)$ & $589(+18.5)$ \\
\hline 2014 & $13838(+4.8)$ & $339(-1.5)$ & $775(+18.3)$ & $565(-4.1)$ \\
\hline 2015 & $13994(+1.1)$ & $273(-19.5)$ & $720(-7.1)$ & $561(-0.7)$ \\
\hline
\end{tabular}

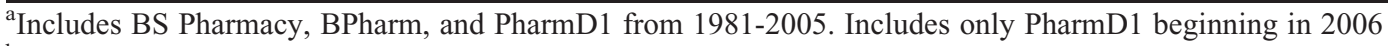

${ }^{\mathrm{b}} \mathrm{PharmD} 2$ refers to the doctor of pharmacy degree awarded as a postbaccalaureate degree

more races accounted for 2.3 percent of all first professional degree enrollments. Students where race/ethnicity was unknown accounted for 4.0 percent of enrollees. Enrollments of underrepresented minorities (Black or African American, Hispanic or Latino, Native Hawaiian or Other Pacific Islander, American Indian or Alaska Native) as a percentage of total enrollments in the Pharm.D. as a first professional degree programs increased to 13.6 percent in fall 2015 from 12.4 percent in fall 2014 [Table 15].

Eight colleges and schools reported 936 students who already held a baccalaureate in pharmacy enrolled in doctor of pharmacy degree programs (Pharm.D.2). This was an increase of 0.1 percent from fall 2014.
Underrepresented minorities accounted for 22.8 percent of these students (Black or African American, 20.4 percent; Hispanic, 1.7 percent; Native Hawaiians/Other Pacific Islander, 0.2 percent; American Indians/Alaska Native, 0.4 percent). White Americans comprised 25.4 percent; Asian Americans, 21.9 percent; students of two or more races, 0.0 percent; unknown, 16.0 percent; and international/foreign students, 13.9 percent.

\section{Graduate Degree Programs}

In fall 2015, the discipline of pharmaceutics had the highest percentage of full-time enrollees at both the M.S. and Ph.D. levels (36.6 percent and 37.2 percent, 
American Journal of Pharmaceutical Education 2016; 80 (6) Article S3.

Table 6. Percentage of Pharmacy Degrees Conferred 1980-2015 by Gender

\begin{tabular}{|c|c|c|c|c|c|c|c|c|c|c|c|c|}
\hline \multirow[b]{2}{*}{ Year } & \multicolumn{2}{|c|}{ BS Pharmacy ${ }^{\mathrm{a}}$} & \multicolumn{2}{|c|}{ PharmD1 $^{\text {b }}$} & \multicolumn{2}{|c|}{ First Professional $^{\mathrm{c}}$} & \multicolumn{2}{|c|}{ PharmD2 $^{\mathrm{d}}$} & \multicolumn{2}{|c|}{ MS } & \multicolumn{2}{|c|}{ PhD } \\
\hline & $\mathbf{M}$ & $\mathbf{F}$ & $\mathbf{M}$ & $\mathbf{F}$ & M & $\mathbf{F}$ & $\mathbf{M}$ & $\mathbf{F}$ & $\mathbf{M}$ & $\mathbf{F}$ & $\mathbf{M}$ & $\mathbf{F}$ \\
\hline 1980 & 59.5 & 40.5 & 59.7 & 40.3 & 59.5 & 40.5 & 66.7 & 33.3 & 67.7 & 32.3 & 82.0 & 18.0 \\
\hline 1981 & 54.6 & 45.4 & 58.4 & 41.6 & 54.9 & 45.1 & 51.9 & 48.1 & 62.4 & 37.6 & 84.4 & 15.6 \\
\hline 1982 & 53.0 & 47.0 & 52.8 & 47.2 & 53.0 & 47.0 & 57.5 & 42.5 & 64.0 & 36.0 & 80.2 & 19.8 \\
\hline 1983 & 50.6 & 49.4 & 52.7 & 47.3 & 50.7 & 49.3 & 50.2 & 49.8 & 65.0 & 35.0 & 74.0 & 26.0 \\
\hline 1984 & 51.0 & 49.0 & 45.1 & 54.9 & 50.5 & 49.5 & 51.1 & 48.9 & 64.2 & 35.8 & 76.7 & 23.3 \\
\hline 1985 & 45.9 & 54.1 & 47.8 & 52.2 & 46.1 & 53.9 & 54.0 & 46.0 & 62.1 & 37.9 & 75.4 & 24.6 \\
\hline 1986 & 45.7 & 54.3 & 45.6 & 54.4 & 45.7 & 54.3 & 46.2 & 53.8 & 59.0 & 41.0 & 73.8 & 26.2 \\
\hline 1987 & 43.3 & 56.7 & 42.2 & 57.8 & 43.1 & 56.9 & 40.6 & 59.4 & 56.6 & 43.4 & 71.7 & 28.3 \\
\hline 1988 & 41.8 & 58.2 & 39.6 & 60.4 & 41.5 & 58.5 & 46.5 & 53.5 & 55.0 & 45.0 & 71.5 & 28.5 \\
\hline 1989 & 40.4 & 59.6 & 37.4 & 62.6 & 40.0 & 60.0 & 44.6 & 55.4 & 57.8 & 42.2 & 61.0 & 39.0 \\
\hline 1990 & 39.8 & 60.2 & 41.0 & 59.0 & 40.0 & 60.0 & 39.1 & 60.9 & 52.5 & 47.5 & 66.3 & 33.7 \\
\hline 1991 & 38.3 & 61.7 & 36.5 & 63.5 & 38.0 & 62.0 & 39.1 & 60.9 & 51.9 & 48.1 & 64.2 & 35.8 \\
\hline 1992 & 38.3 & 61.7 & 35.9 & 64.1 & 37.9 & 62.1 & 43.4 & 56.6 & 52.5 & 47.5 & 61.5 & 38.5 \\
\hline 1993 & 37.2 & 62.8 & 34.1 & 65.9 & 36.6 & 63.4 & 35.6 & 64.4 & 49.2 & 50.8 & 64.1 & 35.9 \\
\hline 1994 & 37.0 & 63.0 & 32.0 & 68.0 & 36.1 & 63.9 & 36.2 & 63.8 & 51.3 & 48.7 & 61.9 & 38.1 \\
\hline 1995 & 36.8 & 63.2 & 34.2 & 65.8 & 36.3 & 63.7 & 38.4 & 61.6 & 47.7 & 52.3 & 62.3 & 37.7 \\
\hline 1996 & 37.5 & 62.5 & 31.8 & 68.2 & 36.2 & 63.8 & 36.1 & 63.9 & 51.4 & 48.6 & 61.2 & 38.8 \\
\hline 1997 & 38.4 & 61.7 & 34.5 & 65.5 & 37.4 & 62.6 & 37.4 & 62.6 & 47.8 & 52.2 & 60.9 & 39.1 \\
\hline 1998 & 38.1 & 61.9 & 31.5 & 68.5 & 35.8 & 64.2 & 34.6 & 65.4 & 46.8 & 53.2 & 57.9 & 42.1 \\
\hline 1999 & 39.4 & 60.6 & 33.1 & 66.9 & 36.5 & 63.5 & 34.5 & 65.5 & 44.8 & 55.2 & 61.6 & 38.4 \\
\hline 2000 & 37.7 & 62.3 & 33.3 & 66.7 & 35.1 & 64.9 & 37.0 & 63.0 & 43.5 & 56.5 & 53.9 & 46.1 \\
\hline 2001 & 39.4 & 60.6 & 34.0 & 66.0 & 35.5 & 64.5 & 37.5 & 62.5 & 39.5 & 60.5 & 56.3 & 43.7 \\
\hline 2002 & 38.2 & 61.8 & 33.4 & 66.6 & 34.3 & 65.7 & 35.4 & 64.6 & 40.2 & 59.8 & 57.4 & 42.6 \\
\hline 2003 & 36.1 & 63.9 & 35.1 & 64.9 & 35.2 & 64.8 & 37.8 & 62.2 & 42.2 & 57.8 & 54.7 & 45.3 \\
\hline 2004 & 39.4 & 60.6 & 33.1 & 66.9 & 33.4 & 66.6 & 36.6 & 63.4 & 42.1 & 57.9 & 52.5 & 47.5 \\
\hline 2005 & 61.5 & 38.5 & 31.8 & 68.2 & 31.9 & 68.1 & 36.1 & 63.9 & 37.2 & 62.8 & 50.1 & 49.9 \\
\hline 2006 & NA & NA & 31.8 & 68.2 & 31.8 & 68.2 & 39.2 & 60.8 & 37.5 & 62.5 & 57.0 & 43.0 \\
\hline 2007 & NA & NA & 32.3 & 67.7 & 32.3 & 67.7 & 20.6 & 79.4 & 39.1 & 60.9 & 53.4 & 46.6 \\
\hline 2008 & NA & NA & 34.0 & 66.0 & 34.0 & 66.0 & 35.9 & 64.1 & 37.6 & 62.4 & 56.0 & 44.0 \\
\hline 2009 & NA & NA & 35.6 & 64.4 & 35.6 & 64.4 & 33.9 & 66.1 & 48.4 & 51.6 & 49.8 & 50.2 \\
\hline 2010 & NA & NA & 37.3 & 62.7 & 37.3 & 62.7 & 36.2 & 63.8 & 44.4 & 55.6 & 54.0 & 46.0 \\
\hline 2011 & NA & NA & 38.2 & 61.8 & 38.2 & 61.8 & 40.2 & 59.8 & 42.8 & 57.2 & 53.1 & 46.9 \\
\hline 2012 & NA & NA & 38.8 & 61.2 & 38.8 & 61.2 & 36.7 & 63.3 & 43.8 & 56.2 & 55.3 & 44.7 \\
\hline 2013 & NA & NA & 38.3 & 61.7 & 38.3 & 61.7 & 38.4 & 61.6 & 40.5 & 59.5 & 49.7 & 50.3 \\
\hline 2014 & NA & NA & 39.6 & 60.4 & 39.6 & 60.4 & 32.4 & 67.6 & 43.9 & 56.1 & 52.7 & 47.3 \\
\hline 2015 & NA & NA & 38.4 & 61.6 & 38.4 & 61.6 & 32.2 & 67.8 & 45.3 & 54.7 & 55.6 & 44.4 \\
\hline
\end{tabular}

${ }^{a}$ Includes BPharm degree

${ }^{\mathrm{b}} \mathrm{PharmD} 1$ refers to the doctor of pharmacy degree awarded as the first professional degree

${ }^{c}$ Includes BS Pharmacy, BPharm, and PharmD1 from 1981-2005. Includes only PharmD1 beginning in 2006

${ }^{\mathrm{d}} \mathrm{PharmD} 2$ refers to the doctor of pharmacy degree awarded as a postbaccalaureate degree

$\mathrm{NA}=$ not applicable

respectively). At the master's level, 24.6 percent of the students were in enrolled in social and administrative sciences programs; 16.5 percent in pharmacology programs; 9.3 percent in pharmacy practice programs; 7.5 percent in medicinal chemistry programs; and 5.5 percent in other disciplines. At the doctoral level, 24.0 percent of the students were enrolled in medicinal chemistry programs; 17.1 percent in pharmacology programs; 10.0 percent in social and administrative science programs; 8.4 percent in other disciplines; and 3.3 percent in pharmacy practice [Table 16].

In fall 2015, more females than males were enrolled full-time in M.S. degree programs (females, 57.6 percent; males, 42.4 percent). Women accounted for 47.1 percent of the students enrolled full-time in Ph.D. programs in 2015, a slight increase from 47.0 percent in 2014.

Of the 1,127 students enrolled full-time in M.S. degree programs in fall 2015 , the majority (58.6 percent) 
American Journal of Pharmaceutical Education 2016; 80 (6) Article S3.

Table 7. Percentage of First Professional Degree (BS Pharmacy, BPharm, and PharmD1) Recipients 1980-2015 by Race/Ethnicity

\begin{tabular}{|c|c|c|c|c|c|c|c|c|c|}
\hline Year & $\begin{array}{l}\text { White }^{\mathrm{a}} \\
\text { n (\%) }\end{array}$ & $\begin{array}{c}\begin{array}{c}\text { Black or } \\
\text { African } \\
\text { American }\end{array} \\
\text { n (\%) }\end{array}$ & $\begin{array}{c}\begin{array}{c}\text { Hispanic or } \\
\text { Latino }^{\mathbf{a}}\end{array} \\
\text { n (\%) }\end{array}$ & $\begin{array}{c}\text { Asian }^{\mathrm{a}} \\
\mathrm{n}(\%)\end{array}$ & $\begin{array}{c}\text { Native } \\
\text { Hawaiian or } \\
\text { Other Pacific } \\
\text { Islander }^{\mathrm{a}} \\
\mathbf{n}(\%)\end{array}$ & $\begin{array}{c}\text { American } \\
\text { Indian or } \\
\text { Alaska } \\
\text { Native }^{\mathrm{a}} \\
\text { n (\%) }\end{array}$ & $\begin{array}{c}\begin{array}{c}\text { Two or } \\
\text { More } \\
\text { Races }^{\mathrm{a}}\end{array} \\
\text { n (\%) }\end{array}$ & $\frac{\text { Unknown }^{\mathrm{a}}}{\mathrm{n}(\%)}$ & $\frac{\begin{array}{c}\text { International/ } \\
\text { Foreign }^{\mathbf{b}}\end{array}}{\text { n (\%) }}$ \\
\hline 1980 & $6335(85.2)$ & 249 (3.4) & $277(3.7)$ & 292 (3.9) & NA & $8(0.1)$ & NA & $49(0.7)$ & $222(3.0)$ \\
\hline 1981 & $6205(84.7)$ & $230(3.1)$ & $361(4.9)$ & 288 (3.9) & NA & $5(0.1)$ & NA & $7(0.1)$ & $227(3.1)$ \\
\hline 1982 & $5810(84.7)$ & $250(3.6)$ & $241(3.5)$ & 317 (4.6) & NA & $13(0.2)$ & NA & $18(0.3)$ & $210(3.1)$ \\
\hline 1983 & $5189(81.4)$ & $241(3.8)$ & $261(4.1)$ & $316(5.0)$ & NA & $8(0.1)$ & NA & $93(1.5)$ & $266(4.2)$ \\
\hline 1984 & $4676(78.4)$ & $242(4.1)$ & 217 (3.6) & $339(5.7)$ & NA & $10(0.2)$ & NA & $174(2.9)$ & $305(5.1)$ \\
\hline 1985 & $4591(80.1)$ & $250(4.4)$ & $245(4.3)$ & $320(5.6)$ & NA & $6(0.1)$ & NA & $8(0.1)$ & $315(5.5)$ \\
\hline 1986 & $4534(78.2)$ & $306(5.3)$ & $217(3.7)$ & $333(5.7)$ & NA & $11(0.2)$ & NA & $0(0.0)$ & 399 (6.9) \\
\hline 1987 & $4559(77.9)$ & $298(5.1)$ & $258(4.4)$ & $371(6.3)$ & NA & $8(0.1)$ & NA & $15(0.3)$ & 345 (5.9) \\
\hline 1988 & $4943(79.9)$ & $282(4.6)$ & $248(4.0)$ & 335 (5.4) & NA & $12(0.2)$ & NA & $27(0.4)$ & 337 (5.4) \\
\hline 1989 & $5040(76.8)$ & $310(4.7)$ & $249(3.8)$ & 454 (6.9) & NA & $12(0.2)$ & NA & $90(1.4)$ & $405(6.2)$ \\
\hline 1990 & $5303(76.2)$ & $368(5.3)$ & $254(3.7)$ & $586(8.4)$ & NA & $11(0.2)$ & NA & $88(1.3)$ & $5.0)$ \\
\hline 1991 & $5381(75.6)$ & 350 (4.9) & $288(4.1)$ & $745(10.5)$ & NA & $0.3)$ & NA & $58(($ & $280(3.9)$ \\
\hline 1992 & $5304(74.6)$ & $381(5.4)$ & 289 (4.1) & $771(10.8)$ & NA & $20(0.3)$ & NA & $40(0.6)$ & $308(4.3)$ \\
\hline 1993 & $5346(72.4)$ & $452(6.1)$ & $260(3.5)$ & $873(11.8)$ & NA & $19(0.3)$ & NA & $124(1.7)$ & (4.1) \\
\hline 1994 & $5476(73.0)$ & $385(5.1)$ & 269 (3.6) & $972(13.0)$ & NA & $23(0.3)$ & NA & 122 (1.6) & 3.4) \\
\hline 1995 & $5584(71.3)$ & $445(5.7)$ & $282(3.6)$ & $1161(14.8)$ & NA & $28(0.4)$ & NA & $48(0.6)$ & $289(3.7)$ \\
\hline 1996 & $5527(69.1)$ & $528(6.6)$ & $266(3.3)$ & $1328(16.6)$ & NA & $25(0.3)$ & NA & $56(0.7)$ & $273(3.4)$ \\
\hline 1997 & $5364(69.0)$ & $446(5.7)$ & $282(3.6)$ & $1363(17.5)$ & NA & $34(0.4)$ & NA & $45(0.6)$ & $238(3.1)$ \\
\hline 1998 & $5041(68.1)$ & $444(6.0)$ & $264(3.6)$ & $1404(19.0)$ & NA & $26(0.4)$ & NA & $58(0.8)$ & $163(2.2)$ \\
\hline 1999 & 4597 (64.4) & $401(5.6)$ & $266(3.7)$ & 1327 (18.6) & NA & $36(0.5)$ & NA & $366(5.1)$ & $148(2.1)$ \\
\hline 2000 & 4517 (62.2) & 480 (6.6) & $287(4.0)$ & 1505 (20.7) & NA & $44(0.6)$ & NA & 223 (3.1) & $204(2.8)$ \\
\hline 2001 & 4469 (63.8) & $428(6.1)$ & $253(3.6)$ & $1456(20.8)$ & NA & $26(0.4)$ & NA & $194(2.8)$ & $174(2.5)$ \\
\hline 2002 & 4648 (61.4) & $575(7.6)$ & $303(4.0)$ & $1625(21.5)$ & NA & $47(0.6)$ & NA & $198(2.6)$ & $177(2.3)$ \\
\hline 2003 & 4473 (59.7) & $591(7.9)$ & 310 (4.1) & 1691 (22.6) & NA & $38(0.5)$ & NA & $182(2.4)$ & $203(2.7)$ \\
\hline 2004 & 4954 (60.7) & $612(7.5)$ & 295 (3.6) & $1857(22.8)$ & NA & $32(0.4)$ & NA & $190(2.3)$ & 218 (2.7) \\
\hline 2005 & $5031(60.8)$ & $720(8.7$ & $361(4.4$ & 1683 (20.4) & NA & $52(0.6$ & NA & $226(2.7)$ & 195 (2.4) \\
\hline $2006^{c}$ & $5650(62.5)$ & $668(7.4)$ & $377(4.2)$ & $1822(20.2)$ & NA & $39(0.4)$ & NA & $265(2.9)$ & $219(2.4)$ \\
\hline 2007 & $6182(63.0)$ & $682(7.0)$ & $386(3.9)$ & $1970(20.1)$ & NA & $53(0.5)$ & NA & 337 (3.4) & $202(2.1)$ \\
\hline 2008 & $6560(62.5)$ & $702(6.7)$ & 407 (3.9) & $2106(20.1)$ & NA & $61(0.6)$ & NA & $424(4.0)$ & $240(2.3)$ \\
\hline 2009 & 6660 (60.6) & $688(6.3)$ & 454 (4.1) & $2333(21.2)$ & NA & $64(0.6)$ & NA & 497 (4.5) & $292(2.7)$ \\
\hline 2010 & $6880(59.9)$ & $744(6.5)$ & 489 (4.3) & $2463(21.4)$ & NA & $50(0.4)$ & NA & $602(5.2)$ & $259(2.3)$ \\
\hline 2011 & $7136(59.8)$ & $763(6.4)$ & $512(4.3)$ & $2570(21.5)$ & $43(0.4)$ & $42(0.4)$ & $37(0.3)$ & $520(4.4)$ & $308(2.6)$ \\
\hline 2012 & 7396 (58.1) & $832(6.5)$ & $532(4.2)$ & 2784 (21.9) & 198 (1.6) & $61(0.5)$ & $98(0.8)$ & $537(4.2)$ & $281(2.2)$ \\
\hline 2013 & 7479 (56.6) & 916 (6.9) & $563(4.3)$ & $3024(22.9)$ & & $52(0.4)$ & $91(0.7)$ & 744 (5.6) & $293(2.2)$ \\
\hline 2014 & & $942(6.8)$ & & & & & $174(1.3)$ & 844 (6.1) & $303(2.2)$ \\
\hline 2015 & 7653 (54.7) & 961 (6.9) & $578(4.1)$ & 3437 (24.6) & $44(0.3)$ & $63(0.5)$ & 248 (1.8) & 605 (4.3) & 405 (2.9) \\
\hline
\end{tabular}

${ }^{\mathrm{a} U}$ U.S. citizen or permanent resident

${ }^{b}$ Citizens of a foreign country/permanent residents of a country other than the U.S

${ }^{\mathrm{c}}$ Includes only Pharm.D.1 degrees from 2006 onward

NA: Not available

were foreign students. White Americans comprised 21.2 percent of enrollees and Asian Americans accounted for 9.0 percent. Underrepresented minorities accounted for 8.2 percent of M.S. enrollees (Black or African American, 2.8 percent; Hispanic or Latino, 4.9 percent; Native Hawaiian or Other Pacific Islander, 0.4 percent; American Indian or Alaska Native, 0.1 percent). Americans of two or more races made up 1.2 percent of enrollees and 2.0 percent of all full-time M.S. degree enrollees were reported as race/ethnicity unknown.

Of the 3,294 students enrolled full-time in Ph.D. degree programs in fall 2015, foreign students were also the largest group, accounting for 51.0 percent of the enrollees. White Americans were the next largest group at 29.8 
American Journal of Pharmaceutical Education 2016; 80 (6) Article S3.

Table 8. Percentage of Postbaccalaureate Doctor of Pharmacy Degree (PharmD2) Recipients 1980-2015 by Race/Ethnicity

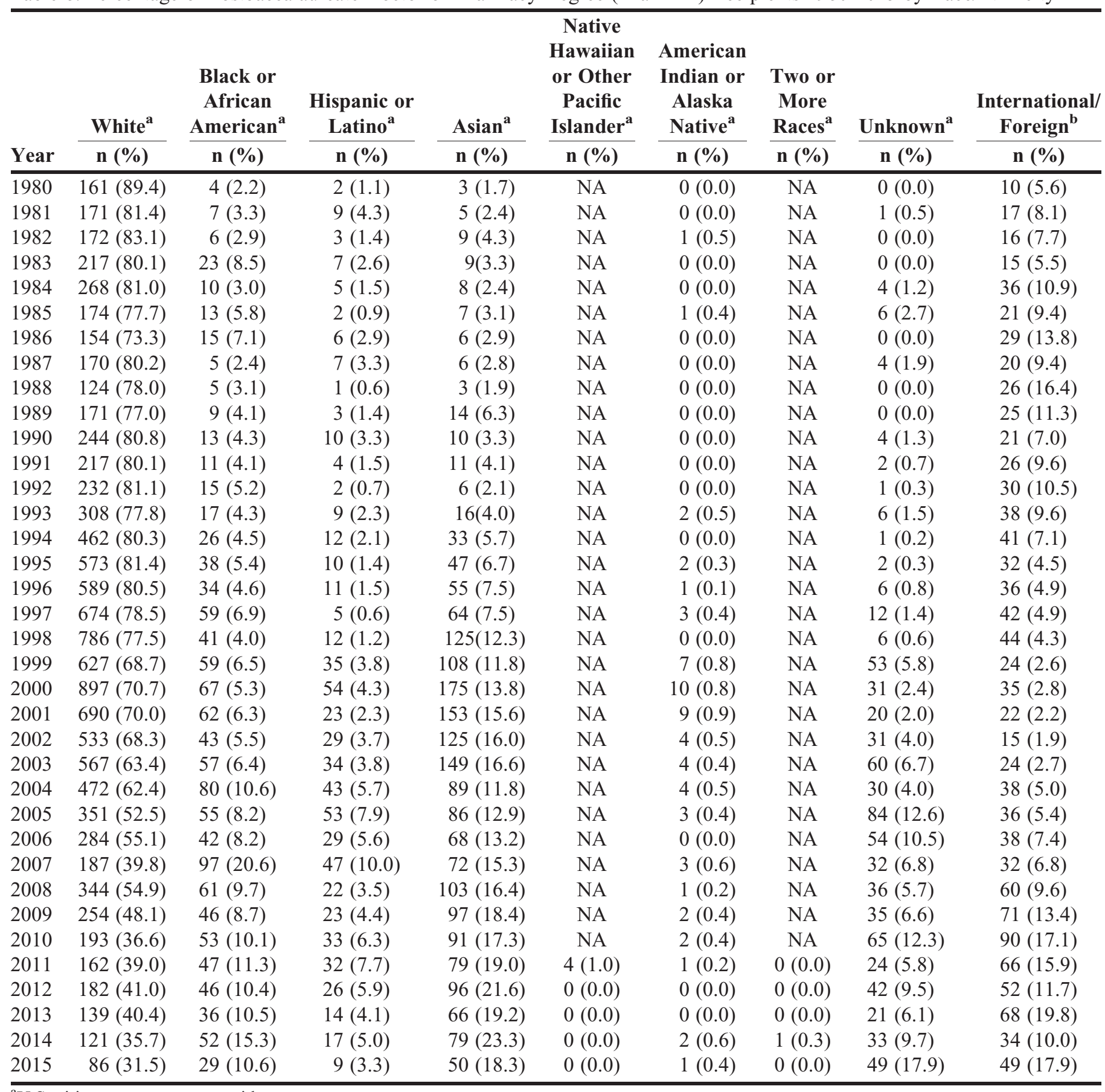

${ }^{a}$ U.S. citizen or permanent resident

${ }^{b}$ Citizens of a foreign country/permanent residents of a country other than the U.S

NA: Not available

percent of full time enrollments, followed by Asian Americans 9.4 percent. Underrepresented minorities accounted for 6.6 percent of Ph.D. enrollees (Black or African American, 4.1 percent; Hispanic or Latino, 2.1 percent; Native Hawaiian or Other Pacific Islander, 0.1 percent; American Indian or Alaska Native, 0.2 percent). Americans of two or more races accounted for 0.9 percent and 2.2 percent of all full-time Ph.D. degree enrollees were reported as unknown. Over 41 percent (41.8) of full-time and part-time students in $\mathrm{Ph}$.D. programs held a professional pharmacy degree, 10.5 percent of Ph.D. students held a professional pharmacy degree from a U.S. college or school of pharmacy and 31.3 percent held a pharmacy degree conferred by a non-U.S. institution [Table 17]. 


\section{American Journal of Pharmaceutical Education 2016; 80 (6) Article S3.}

Table 9. Summary of Master of Science and Doctor of Philosophy Degrees Conferred 2014-15 by Gender and Discipline

\begin{tabular}{|c|c|c|c|c|c|c|c|c|}
\hline \multirow[b]{2}{*}{ Discipline } & \multicolumn{4}{|c|}{ MS Degree } & \multicolumn{4}{|c|}{ PhD Degree } \\
\hline & $\mathbf{M}$ & $\mathbf{F}$ & Total & $\begin{array}{c}\text { \% MS Degrees } \\
\text { Conferred }\end{array}$ & $\mathbf{M}$ & $\mathbf{F}$ & Total & $\begin{array}{c}\text { \% PhD Degree } \\
\text { Conferred }\end{array}$ \\
\hline Pharmacology & 67 & 72 & 139 & 19.3 & 55 & 39 & 94 & 16.8 \\
\hline Social and administrative sciences & 87 & 94 & 181 & 25.1 & 26 & 27 & 53 & 9.4 \\
\hline Pharmacy practice & 16 & 24 & 40 & 5.6 & 7 & 11 & 18 & 3.2 \\
\hline Other $^{\mathrm{a}}$ & 42 & 72 & 114 & 15.8 & 30 & 16 & 46 & 8.2 \\
\hline Total & 326 & 394 & 720 & & 312 & 249 & 561 & \\
\hline
\end{tabular}

${ }^{a}$ Includes Biophysics/Biological \& Medical Informatics, Biochemistry/Toxicology \& Immunology, Pharmacometrics, Informatics, Regulatory Affairs \& Quality Assurance/Compliance, and Regulatory Affairs in MS programs and Bioengineering/Biophysics/Biological \& Medical Informatics, Pharmacotherapy \& Translational Research, Pharmaceutical \& Biomedical Science, Neuroscience, and Pharmaceutical \& Pharmacological Sciences in $\mathrm{PhD}$ programs

\section{ACKNOWLEDGMENTS}

The American Association of Colleges of Pharmacy wishes to express its appreciation to the deans of its member institutions and members of their faculty and staff who devoted their valuable time to complete the surveys that led to this report. This report is an excerpt from the Profile of Pharmacy Students - Fall 2015, published by the American Association of Colleges of Pharmacy (2016). 
American Journal of Pharmaceutical Education 2016; 80 (6) Article S3.

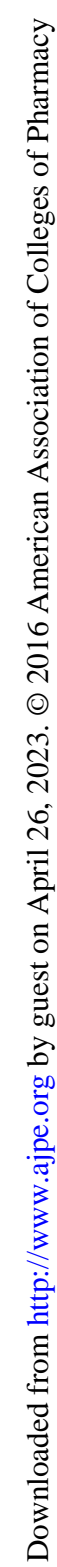

ำ

|

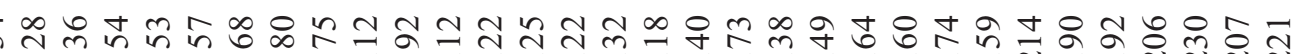

$\Sigma$

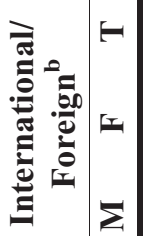

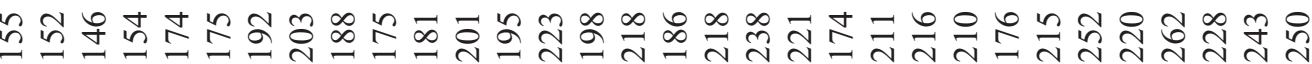

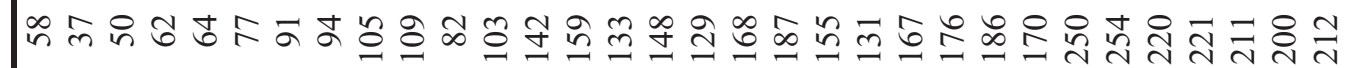

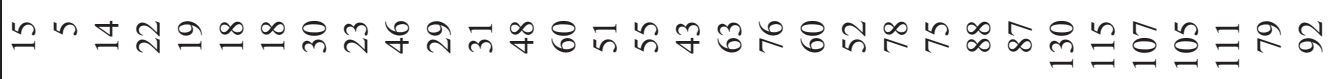

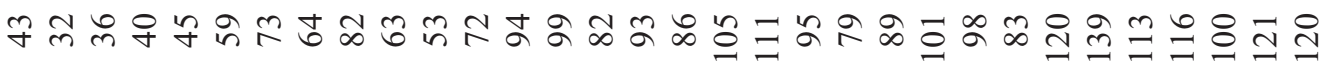

$\approx|+|$ mo-t

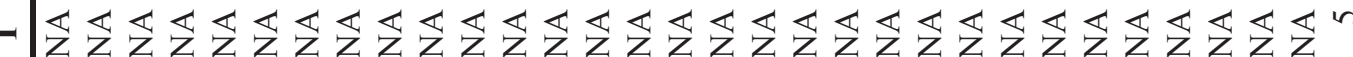

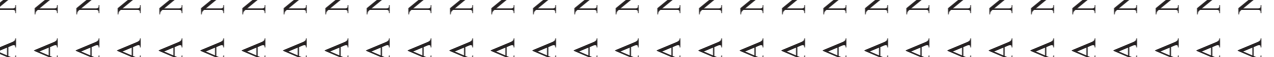

\#ँ"

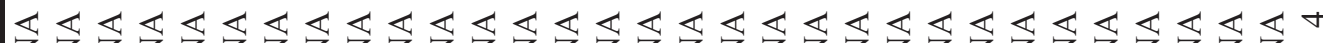

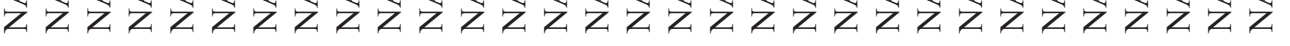

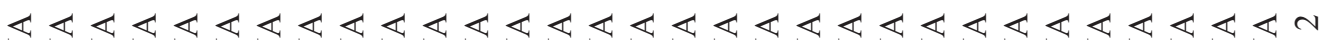

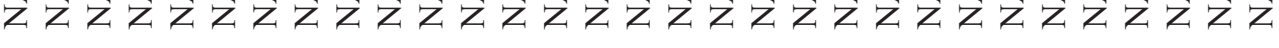

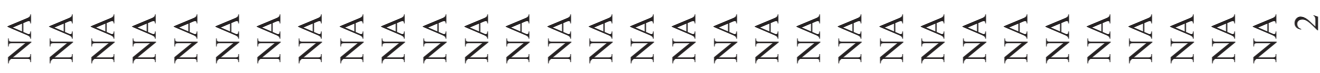

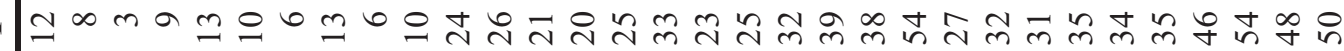

N

○

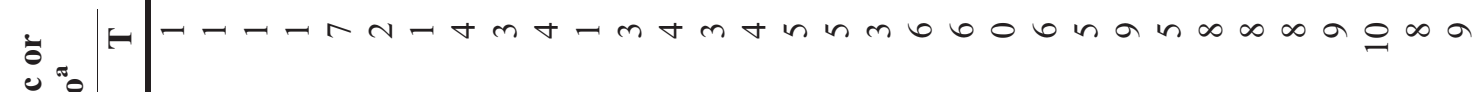

$\because$ *

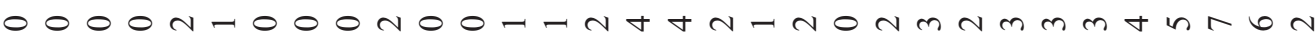

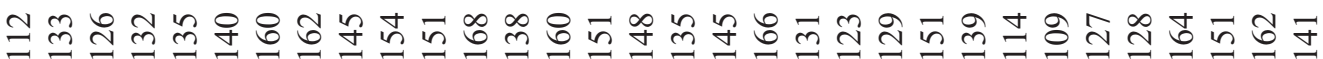
구

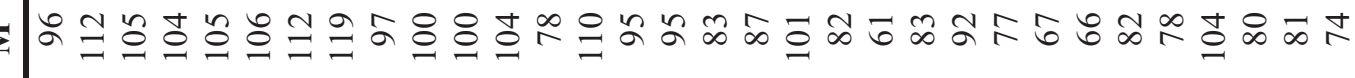

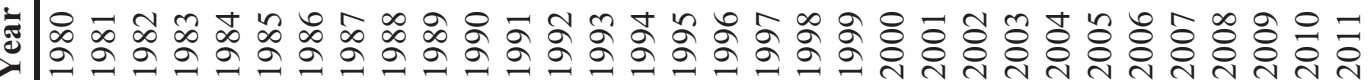


American Journal of Pharmaceutical Education 2016; 80 (6) Article S3.

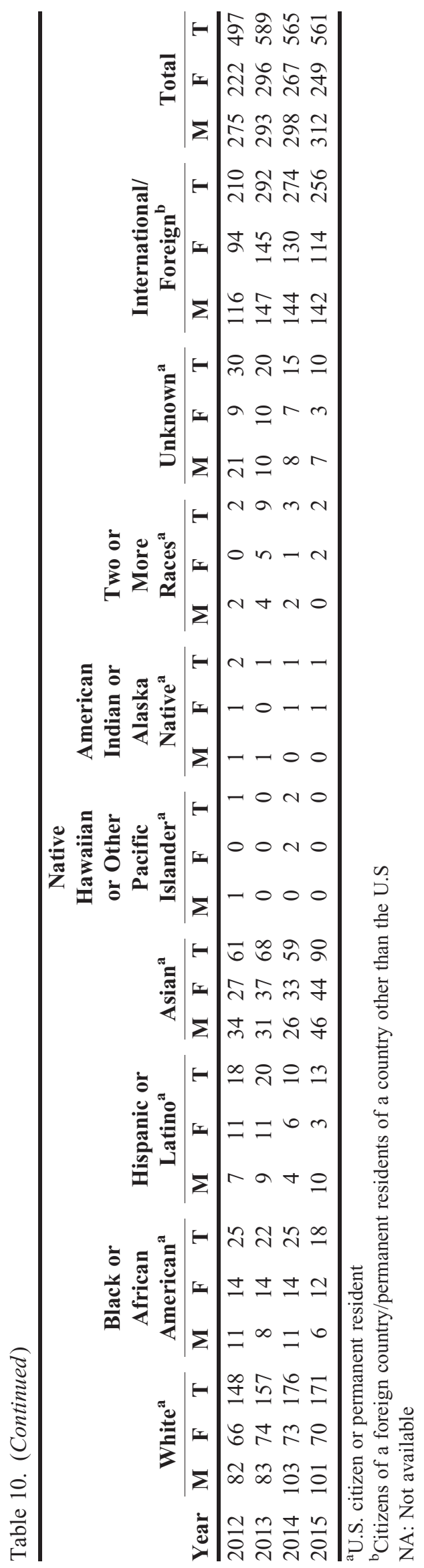


American Journal of Pharmaceutical Education 2016; 80 (6) Article S3.

Table 11. Percentage of Master of Science (MS) Degree Recipients 1990-2015 by Race/Ethnicity

\begin{tabular}{|c|c|c|c|c|c|c|c|c|c|}
\hline Year & $\begin{array}{l}\text { White }^{\text {a }} \\
\text { n (\%) }\end{array}$ & $\begin{array}{c}\begin{array}{c}\text { Black or } \\
\text { African }\end{array} \\
\text { American }^{\mathbf{a}} \\
\text { n (\%) }\end{array}$ & $\begin{array}{c}\begin{array}{c}\text { Hispanic } \\
\text { or Latino }\end{array} \\
\frac{n(\%)}{}\end{array}$ & $\begin{array}{c}\text { Asian }^{a} \\
\text { n (\%) }\end{array}$ & $\begin{array}{c}\text { Native } \\
\text { Hawaiian } \\
\text { or Other } \\
\text { Pacific } \\
\text { Islander }^{\text {a }} \\
\text { n (\%) }\end{array}$ & $\begin{array}{c}\text { American } \\
\text { Indian or } \\
\text { Alaska } \\
\text { Native }^{a} \\
\text { n (\%) }\end{array}$ & $\begin{array}{l}\text { Two or } \\
\text { More } \\
\text { Races }^{\text {a }} \\
\text { n (\%) }\end{array}$ & $\frac{\text { Unknown }^{\mathbf{a}}}{\mathrm{n}(\%)}$ & $\begin{array}{c}\begin{array}{c}\text { International/ } \\
\text { Foreign }^{b}\end{array} \\
\text { n (\%) }\end{array}$ \\
\hline 1980 & $299(64.3)$ & $10(2.2)$ & $3(0.6)$ & $27(5.8)$ & NA & $0(0.0)$ & NA & $41(8.8)$ & $85(18.3)$ \\
\hline 1982 & $282(61.6)$ & $5(1.1)$ & $6(1.3)$ & $6(1.3)$ & NA & $1(0.2)$ & NA & $27(5.9)$ & $131(28.6)$ \\
\hline 1983 & $282(66.2)$ & $2(0.5)$ & $4(0.9)$ & $10(2.3)$ & NA & $0(0.0)$ & NA & $40(9.4)$ & $88(20.7)$ \\
\hline 1984 & $254(64.5)$ & $8(2.0)$ & $4(1.0)$ & $16(4.1)$ & NA & $0(0.0)$ & NA & $21(5.3)$ & $91(23.1)$ \\
\hline 1985 & $215(63.6)$ & $10(3.0)$ & $3(0.9)$ & $11(3.3)$ & NA & $0(0.0)$ & NA & $1(0.3)$ & $98(29.0)$ \\
\hline 1986 & $282(68.0)$ & $6(1.4)$ & $8(1.9)$ & 7 (1.7) & NA & $1(0.2)$ & NA & $0(0.0)$ & $111(26.7)$ \\
\hline 1987 & $231(66.4)$ & $6(1.7)$ & $4(1.1)$ & $11(3.2)$ & NA & $0(0.0)$ & NA & $14(4.0)$ & $82(23.6)$ \\
\hline 1991 & 218 (59.9) & $13(3.6)$ & 7 (1.9) & $27(7.4)$ & NA & $0(0.0)$ & NA & $2(0.5)$ & 97 (26.6) \\
\hline 1992 & $140(49.6)$ & $14(5.0)$ & $9(3.2)$ & $14(5.0)$ & NA & $0(0.0)$ & NA & $5(1.8)$ & $100(35.5)$ \\
\hline 1993 & $149(49.5)$ & $9(3.0)$ & $20(6.6)$ & $13(4.3)$ & NA & $0(0.0)$ & NA & $5(1.7)$ & $105(34.9)$ \\
\hline 1994 & $169(47.6)$ & $8(2.3)$ & $13(3.7)$ & $19(5.4)$ & NA & $0(0.0)$ & NA & $5(1.4)$ & $141(39.7)$ \\
\hline 1995 & $206(52.6)$ & $16(4.1)$ & $16(4.1)$ & $32(8.2)$ & NA & $0(0.0)$ & NA & $1(0.3)$ & $121(30.9)$ \\
\hline 1996 & $236(55.9)$ & $12(2.8)$ & $16(3.8)$ & $23(5.5)$ & NA & $0(0.0)$ & NA & $8(1.9)$ & $127(30.1)$ \\
\hline 1997 & $194(48.5)$ & $18(4.5)$ & $17(4.3)$ & $36(9.0)$ & NA & $0(0.0)$ & NA & $5(1.3)$ & $130(32.5)$ \\
\hline 1998 & $213(50.6)$ & $14(3.3)$ & $19(4.5)$ & $38(9.0)$ & NA & $1(0.2)$ & NA & $13(3.1)$ & $123(29.2)$ \\
\hline 1999 & $173(45.1)$ & $20(5.2)$ & $8(2.1)$ & $31(8.1)$ & NA & $0(0.0)$ & NA & $19(4.9)$ & $133(34.6)$ \\
\hline 2000 & $172(48.6)$ & $13(3.7)$ & $13(3.7)$ & $36(10.2)$ & NA & $1(0.3)$ & NA & $2(0.6)$ & $117(33.1)$ \\
\hline 2008 & $318(43.4)$ & $35(4.8)$ & $33(4.5)$ & $75(10.2)$ & NA & $1(0.1)$ & NA & $64(8.7)$ & $206(28.1)$ \\
\hline 2009 & $186(24.3)$ & $30(3.9)$ & $11(1.4)$ & 85 (11.1) & NA & $0(0.0)$ & NA & $75(9.8)$ & $380(49.5)$ \\
\hline 2010 & $222(28.7)$ & $22(2.8)$ & $22(2.8)$ & $78(10.1)$ & NA & $1(0.1)$ & NA & $73(9.4)$ & $355(45.9)$ \\
\hline 2011 & 235 (28.6) & $38(4.6)$ & $16(1.9)$ & $78(9.5)$ & $2(0.2)$ & $2(0.2)$ & $1(0.1)$ & $66(8.0)$ & $384(46.7)$ \\
\hline 2012 & 217 (31.9) & $24(3.5)$ & $15(2.2)$ & 81 (11.9) & $1(0.1)$ & $4(0.6)$ & $3(0.4)$ & $27(4.0)$ & 309 (45.4) \\
\hline 2013 & 183 (27.9) & $24(3.7)$ & $15(2.3)$ & $72(11.0)$ & $1(0.2)$ & $3(0.5)$ & $7(1.1)$ & $31(4.7)$ & $319(48.7)$ \\
\hline 2014 & $204(26.3)$ & $38(4.9)$ & 15 (1.9) & 75 (9.7) & $3(0.4)$ & $0(0.0)$ & $5(0.6)$ & $49(6.3)$ & $386(49.8)$ \\
\hline 2015 & $207(28.8)$ & $28(3.9)$ & $20(2.8)$ & 84 (11.7) & $0(0.0)$ & $0(0.0)$ & $8(1.1)$ & $22(3.1)$ & $351(48.8)$ \\
\hline
\end{tabular}


American Journal of Pharmaceutical Education 2016; 80 (6) Article S3.

Table 12. Percentage of Doctor of Philosophy Degree (PhD) Recipients 1980-2015 by Race/Ethnicity

\begin{tabular}{|c|c|c|c|c|c|c|c|c|c|}
\hline Year & $\begin{array}{c}\text { White }^{\text {a }} \\
\text { n (\%) }\end{array}$ & $\begin{array}{c}\begin{array}{c}\text { Black or } \\
\text { African }\end{array} \\
\text { American } \\
\text { n (\%) }\end{array}$ & $\begin{array}{c}\begin{array}{c}\text { Hispanic } \\
\text { or Latino }\end{array} \\
\frac{\mathrm{n}(\%)}{}\end{array}$ & $\frac{\text { Asian }^{a}}{\text { n (\%) }}$ & $\begin{array}{c}\text { Native } \\
\text { Hawaiian } \\
\text { or Other } \\
\text { Pacific } \\
\text { Islander }^{\text {a }} \\
\mathbf{n}(\%)\end{array}$ & $\begin{array}{c}\text { American } \\
\text { Indian or } \\
\text { Alaska } \\
\text { Native }^{\text {a }} \\
\text { n (\%) }\end{array}$ & $\begin{array}{l}\text { Two or } \\
\text { More } \\
\text { Races }^{\text {a }} \\
\text { n (\%) }\end{array}$ & $\frac{\text { Unknown }^{\mathbf{a}}}{\mathrm{n}(\%)}$ & $\begin{array}{c}\begin{array}{c}\text { International/ } \\
\text { Foreign }^{\mathbf{b}}\end{array} \\
\mathbf{n}(\%)\end{array}$ \\
\hline 1980 & $112(59.3)$ & $3(1.6)$ & $1(0.5)$ & $12(6.3)$ & NA & $0(0.0)$ & NA & $3(1.6)$ & $58(30.7)$ \\
\hline 1982 & $126(69.2)$ & $1(0.5)$ & $1(0.5)$ & $3(1.6)$ & NA & $0(0.0)$ & NA & $1(0.5)$ & $50(27.5)$ \\
\hline 1983 & $132(63.5)$ & $0(0.0)$ & $1(0.5)$ & $9(4.3)$ & NA & $0(0.0)$ & NA & $4(1.9)$ & $62(29.8)$ \\
\hline 1984 & $135(59.5)$ & $2(0.9)$ & $7(3.1)$ & $13(5.7)$ & NA & $0(0.0)$ & NA & $6(2.6)$ & $64(28.2)$ \\
\hline 1985 & $140(60.3)$ & $2(0.9)$ & $2(0.9)$ & $10(4.3)$ & NA & $1(0.4)$ & NA & $0(0.0)$ & 77 (33.2) \\
\hline 1986 & $160(61.5)$ & $2(0.8)$ & $1(0.4)$ & $6(2.3)$ & NA & $0(0.0)$ & NA & $0(0.0)$ & $91(35.0)$ \\
\hline 1991 & $168(53.7)$ & $8(2.6)$ & $3(1.0)$ & $26(8.3)$ & NA & $0(0.0)$ & NA & $5(1.6)$ & 103 (32.9) \\
\hline 1992 & $138(43.5)$ & $8(2.5)$ & $4(1.3)$ & $21(6.6)$ & NA & $0(0.0)$ & NA & $4(1.3)$ & $142(44.8)$ \\
\hline 1993 & $160(46.0)$ & $5(1.4)$ & $3(0.9)$ & $20(5.7)$ & NA & $1(0.3)$ & NA & $0(0.0)$ & $159(45.7)$ \\
\hline 1994 & $150(46.9)$ & $6(1.9)$ & $4(1.3)$ & $25(7.8)$ & NA & $0(0.0)$ & NA & $2(0.6)$ & 133 (41.6) \\
\hline 1995 & $148(42.3)$ & $10(2.9)$ & $5(1.4)$ & $33(9.4)$ & NA & $2(0.6)$ & NA & $4(1.1)$ & $148(42.3)$ \\
\hline 1996 & $135(44.4)$ & $9(3.0)$ & $5(1.6)$ & $23(7.6)$ & NA & $0(0.0)$ & NA & $3(1.0)$ & $129(42.4)$ \\
\hline 1997 & $145(40.5)$ & $10(2.8)$ & $3(0.8)$ & $25(7.0)$ & NA & $0(0.0)$ & NA & $7(2.0)$ & $168(46.9)$ \\
\hline 1998 & $166(40.4)$ & $14(3.4)$ & $6(1.5)$ & $32(7.8)$ & NA & $2(0.5)$ & NA & $4(1.0)$ & $187(45.5)$ \\
\hline 1999 & $131(36.5)$ & $13(3.6)$ & $6(1.7)$ & 39 (10.9) & NA & $0(0.0)$ & NA & $15(4.2)$ & $155(43.2)$ \\
\hline 2000 & $123(38.1)$ & $11(3.4)$ & $0(0.0)$ & $38(11.8)$ & NA & $0(0.0)$ & NA & $20(6.2)$ & $131(40.6)$ \\
\hline 2008 & $164(35.0)$ & $11(2.4)$ & 9 (1.9) & $46(9.8)$ & NA & $2(0.4)$ & NA & $15(3.2)$ & $221(47.2)$ \\
\hline 2009 & $151(33.0)$ & $18(3.9)$ & $10(2.2)$ & $54(11.8)$ & NA & $0(0.0)$ & NA & $14(3.1)$ & $211(46.1)$ \\
\hline 2010 & $162(36.0)$ & $13(2.9)$ & $8(1.8)$ & $48(10.7)$ & NA & $1(0.2)$ & NA & $18(4.0)$ & $200(44.4)$ \\
\hline 2011 & 141 (29.9) & $34(7.2)$ & $9(1.9)$ & $50(10.6)$ & $4(0.8)$ & $0(0.0)$ & $5(1.1)$ & $16(3.4)$ & $212(45.0)$ \\
\hline 2012 & $148(29.8)$ & $25(5.0)$ & $18(3.6)$ & $61(12.3)$ & $1(0.2)$ & $2(0.4)$ & $2(0.4)$ & $30(6.0)$ & $210(42.3)$ \\
\hline 2013 & $157(26.7)$ & $22(3.7)$ & $20(3.4)$ & 68 (11.5) & $0(0.0)$ & $1(0.2)$ & $9(1.5)$ & $20(3.4)$ & 292 (49.6) \\
\hline 2014 & $176(31.2)$ & $25(4.4)$ & $10(1.8)$ & $59(10.4)$ & $2(0.4)$ & $1(0.2)$ & $3(0.5)$ & $15(2.7)$ & $274(48.5)$ \\
\hline 2015 & $171(30.5)$ & $18(3.2)$ & $13(2.3)$ & $90(16.0)$ & $0(0.0)$ & $1(0.2)$ & $2(0.4)$ & $10(1.8)$ & $256(45.6)$ \\
\hline
\end{tabular}




\section{American Journal of Pharmaceutical Education 2016; 80 (6) Article S3.}

Table 13. Summary of Enrollments in First Professional Degree Programs 1980-2015

\begin{tabular}{|c|c|c|c|}
\hline Year & $\frac{\text { First Professional Year Classes, }}{\text { a }}$ & $\frac{\text { All Professional Years, }}{\text { No. }(\% \text { Change })}$ & $\frac{\text { Total Enrollment, }}{\text { No. (\% Change) }}$ \\
\hline 1980 & 7377 & 22093 & 26617 \\
\hline 1982 & $6609(-4.6)$ & $19350(-5.5)$ & $23410(-5.1)$ \\
\hline 1983 & $6635(0.4)$ & $18831(-2.7)$ & $23091(-1.4)$ \\
\hline 1984 & $6986(5.3)$ & $18646(-1.0)$ & $23312(1.0)$ \\
\hline 1986 & $7554(6.5)$ & $20073(5.1)$ & $25643(3.3)$ \\
\hline 1987 & 7751 (2.6) & $21424(6.7)$ & $27292(6.4)$ \\
\hline 1988 & $7990(3.1)$ & $22447(4.8)$ & $28891(5.9)$ \\
\hline 1989 & $8033(0.5)$ & $23013(2.5)$ & $29560(2.3)$ \\
\hline 1990 & 8267 (2.9) & $23238(1.0)$ & $29797(0.8)$ \\
\hline 1995 & $8740(-4.6)$ & $28060(1.4)$ & $33415(0.2)$ \\
\hline 1996 & $9561(9.4)$ & $28027(-0.1)$ & $33059(-1.1)$ \\
\hline 1997 & $8571(-10.4)$ & $28345(1.1)$ & $32529(-1.6)$ \\
\hline 1998 & $8346(-2.6)$ & $28568(0.8)$ & 33090 (1.7) \\
\hline 1999 & $8123(-2.7)$ & $29586(3.6)$ & $32537(-1.7)$ \\
\hline 2000 & 8382 (3.2) & $30301(2.4)$ & $34481(6.0)$ \\
\hline 2001 & $8922(6.4)$ & $31769(4.8)$ & 35885 (4.1) \\
\hline 2002 & $9128(2.3)$ & $33437(5.3)$ & $38902(8.4)$ \\
\hline 2003 & 9909 (8.6) & $36454(9.0)$ & $41762(10.7)$ \\
\hline 2004 & $10437(5.3)$ & $38544(5.7)$ & $43908\left(-^{c}\right)$ \\
\hline 2012 & $14011(4.1)$ & $56489(4.5)$ & $61275(4.0)$ \\
\hline 2013 & $14008(0.0)$ & $58121(2.9)$ & $62743(2.4)$ \\
\hline 2014 & 14276 (1.9) & $59370(2.1)$ & 63927 (1.9) \\
\hline 2015 & $14190(-0.6)$ & $59720(0.6)$ & $63460(-0.7)$ \\
\hline
\end{tabular}

${ }^{a}$ Includes second from last year for baccalaureate and third from last year for PharmD1 and does not include first year enrollees in accelerated programs from 1980-2005. Includes third from last year PharmD1 beginning in 2006

${ }^{b}$ Includes the final three years only of all first professional degree programs for 1980-1991; includes all professional years for 1992-present (3 years for baccalaureate and 4 years for PharmD)

${ }^{\mathrm{c}}$ Not able to calculate percent change due to change in how data are reported by select institutions 
American Journal of Pharmaceutical Education 2016; 80 (6) Article S3.

Table 14. Summary of Enrollments in First Professional Degree Programs by Gender 1980-2015

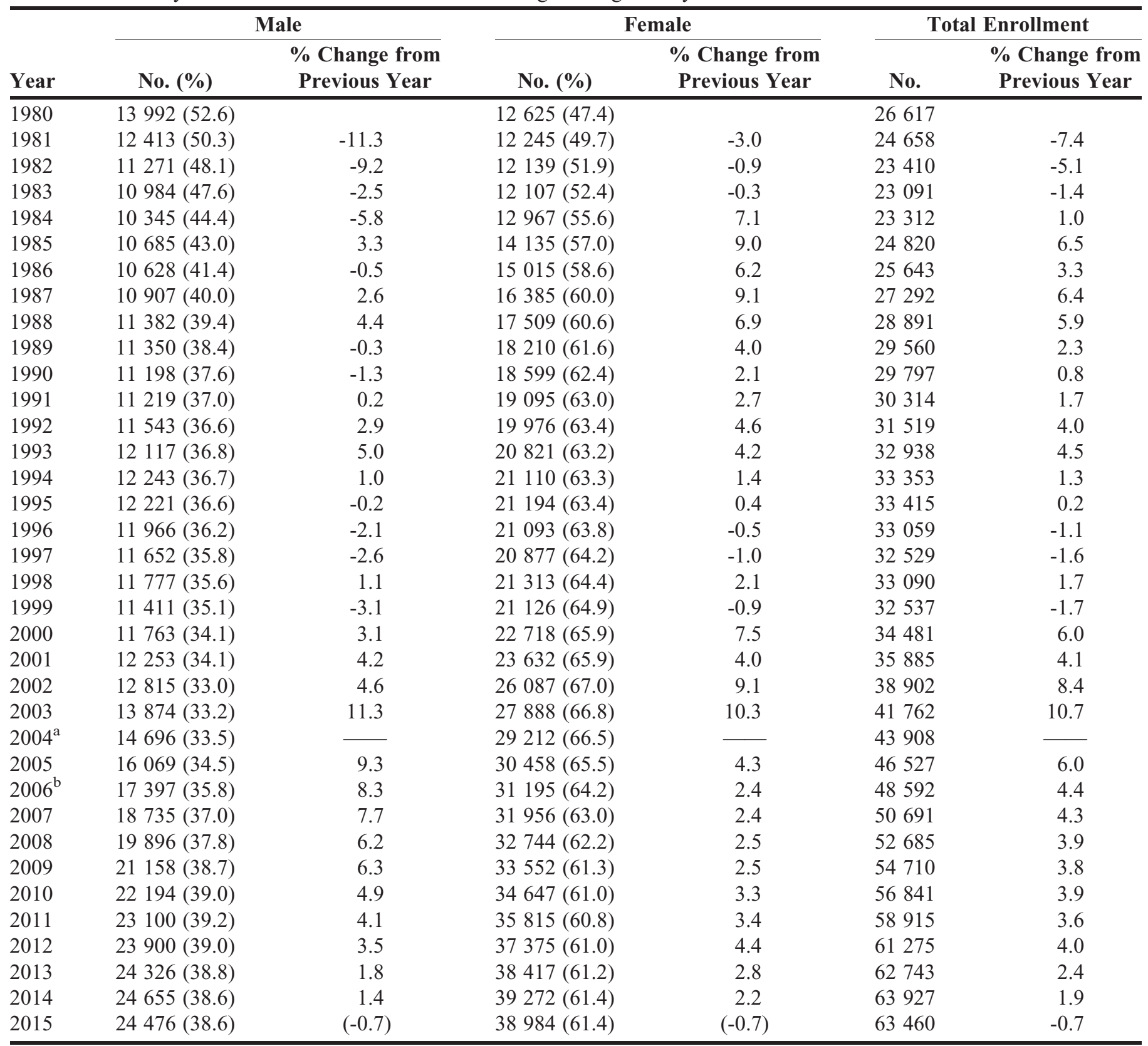

${ }^{a}$ Not able to calculate percent change due to change in how data is reported by select institutions

${ }^{\mathrm{b}}$ Includes only PharmD1 degrees beginning in 2006 
American Journal of Pharmaceutical Education 2016; 80 (6) Article S3.

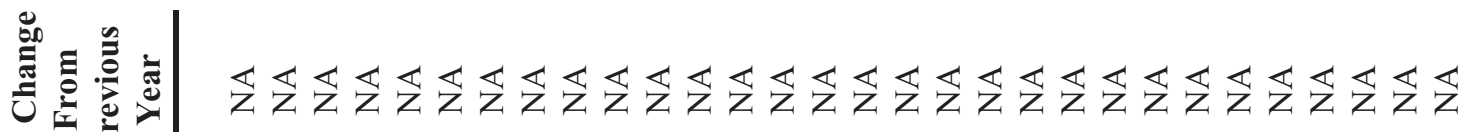
$0^{\circ}$

$\dot{0} \div$

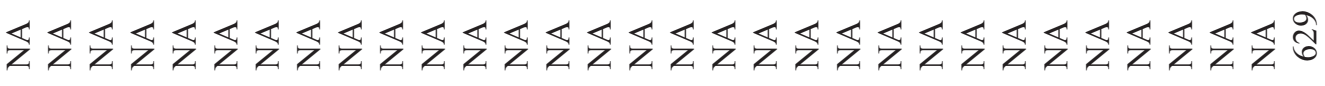

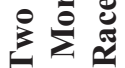

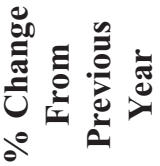

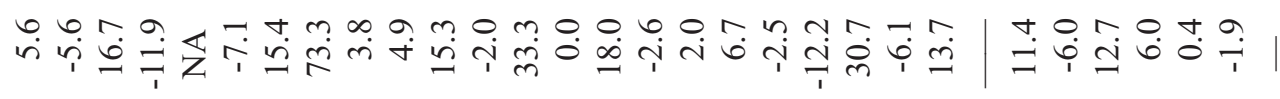

สำ

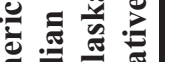

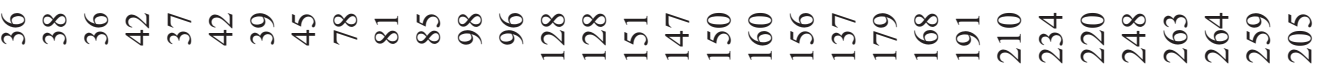

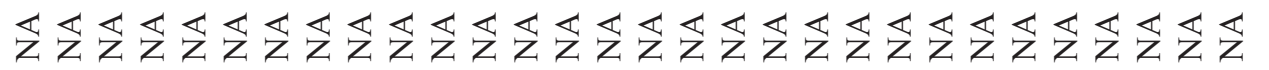

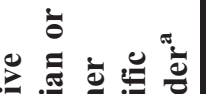

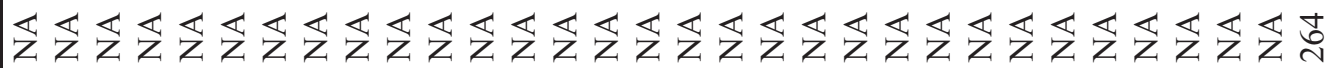

⿶

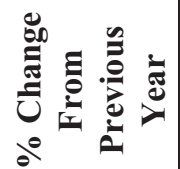

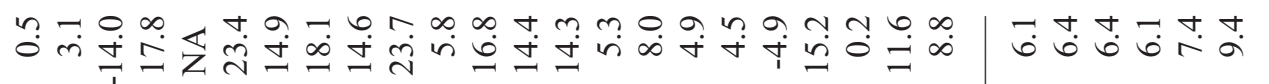

:

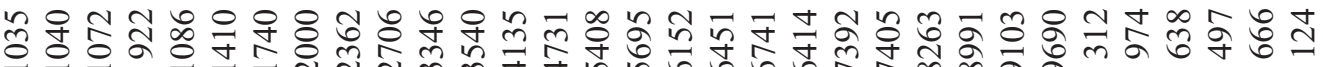

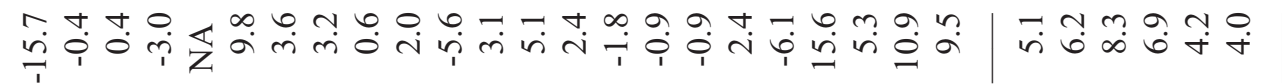

tᄒ

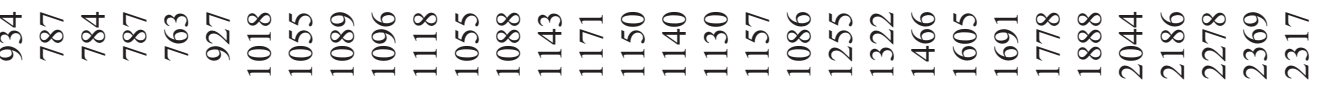

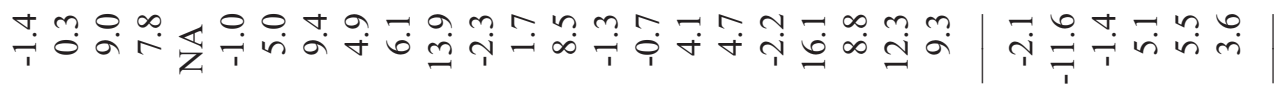


American Journal of Pharmaceutical Education 2016; 80 (6) Article S3.

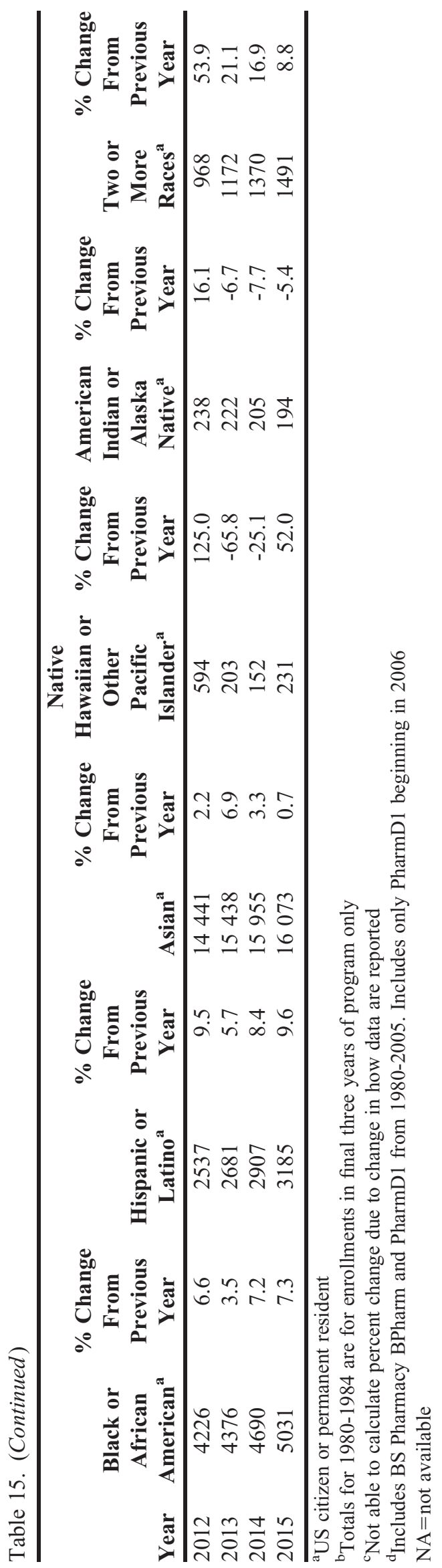




\section{American Journal of Pharmaceutical Education 2016; 80 (6) Article S3.}

Table 16. Summary of Master of Science (MS) and Doctor of Philosophy (PhD) Fall 2015 Full-Time Enrollments by Gender and Discipline

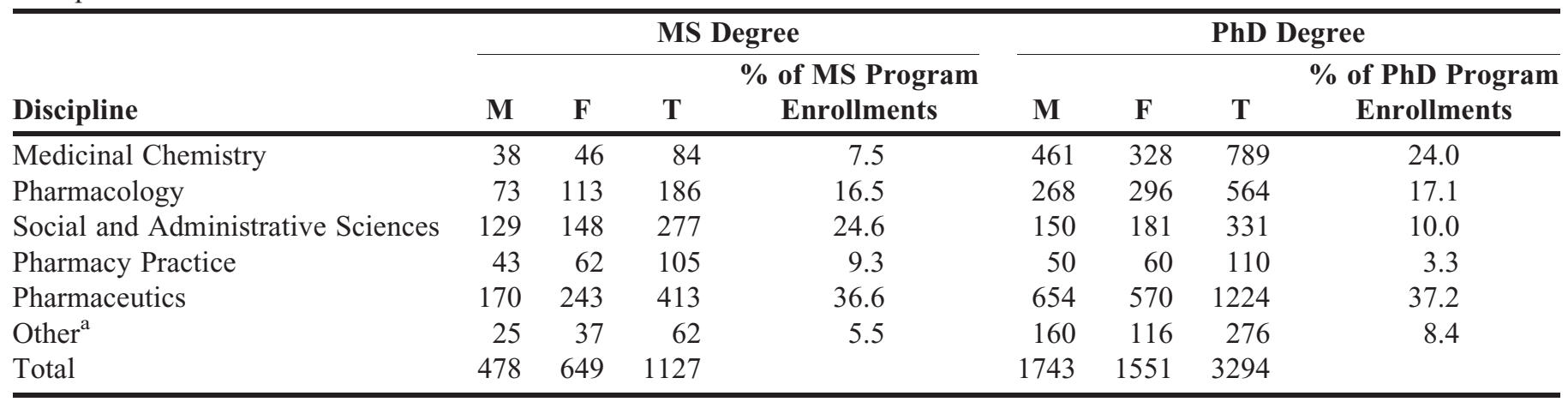

ancludes Pharmacy Studies, Immunology, Pharmaceutical and Biomedical Sciences, Biomedical Sciences/Nanotechnology, Undecided, and Pharmaceutical/Chemical Product Development for MS programs and Bioengineering/Biophysics/Biological \& Medical Informatics, Pharmacotherapy \& Translational Research, Pharmaceutical \& Biomedical Science, Neuroscience, Translational Science, Translational Science \& Psychology, Pharmacotherapy Outcomes \& Health Research, and Pharmaceutical \& Pharmacological Sciences for PhD programs

Table 17. Fall 2015 Enrollments in PhD Programs by Type of Enrollment (Full-Time, Part-Time), Discipline, and Source of Previous Degree Earned ${ }^{\mathrm{a}}$

\begin{tabular}{|c|c|c|c|c|c|c|c|c|}
\hline & \multicolumn{2}{|c|}{ US School } & \multicolumn{2}{|c|}{ Canadian School } & \multicolumn{2}{|c|}{ Foreign School } & \multicolumn{2}{|c|}{ All Schools } \\
\hline & Pharm & Non-pharm & Pharm & Non-pharm & Pharm & Non-pharm & Pharm & Non-pharm \\
\hline \multicolumn{9}{|l|}{ Full-Time } \\
\hline Pharmacology & 39 & 226 & 0 & 1 & 158 & 91 & 197 & 318 \\
\hline Social and Admin. Sciences & 50 & 73 & 2 & 1 & 117 & 42 & 169 & 116 \\
\hline Pharmacy Practice & 20 & 33 & 0 & 0 & 41 & 14 & 61 & 47 \\
\hline Other & 9 & 53 & 0 & 0 & 14 & 17 & 23 & 70 \\
\hline Total full-time & 278 & 1044 & 2 & 4 & 850 & 516 & 1130 & 1564 \\
\hline \multicolumn{9}{|l|}{ Part-Time } \\
\hline Medicinal Chemistry & 1 & 7 & 0 & 0 & 2 & 2 & 3 & 9 \\
\hline Pharmacology & 5 & 22 & 0 & 0 & 3 & 0 & 8 & 22 \\
\hline Social and Admin. Sciences & 2 & 9 & 0 & 0 & 2 & 1 & 4 & 10 \\
\hline Total part-time & 13 & 44 & 0 & 0 & 16 & 8 & 29 & 52 \\
\hline
\end{tabular}

${ }^{a}$ Includes only those students for whom source of degree was reported 